\title{
ANALISIS PERANAN KATEGORI EKONOMI BASIS DAN EFISIENSI PERTAMBAHAN INVESTASI DI KABUPATEN MINAHASA UTARA
}

\author{
Julio Patrice Deo Ratag \\ Vicky V. J. Panelewen \\ Benu Olfie L. S.
}

\begin{abstract}
This research aims to analyze the role of the categorical or economic base sector as well as to observe the efficiency of investment accumulation in North Minahasa Regency. This research was conducted in the area of North Minahasa Regency, North Sulawesi Province. The study began in April until October 2018. This research was conducted in the area of North Minahasa Regency, North Sulawesi Province. The study began in April until October 2018. This research employs secondary data from Regional Gross Domestic Product (RGDP) based on the constant price in North Minahasa Regency and North Sulawesi Province and the data from The Change of Regional Gross Fixed Capital in North Minahasa Regency. The instrument used in this research is Location Quotient (LQ), Shift Share Analysis, and Incremental Capital Output Ratio. Results from $L Q$ show that the category of agriculture, forestry, and fishery, mining and excavation, manufacture, construction, electricity and gas, real estate and education service serve the base category in North Minahasa Regency, with the value of $L Q$ above 1 . The role of base category shows positive result towards the formation of the Regional Gross Domestic Product in North Minahasa Regency, agriculture and forestry and fishery are the biggest contributor in RGDP of North Minahasa Regency during the period of 2013-2017. The role of base category through regional share towards North Sulawesi Province also shows positive results, thus base category in North Minahasa Regency contributes to the formation of RGDP in North Sulawesi Province. In the calculation of proportional shift, several base categories in North Minahasa Regency received negative values, namely agriculture, forestry and fishery, manufacture, and education service. Then, in the calculation of differential shift, electronics and gas is the only sector which receives negative value or is not able to compete with similar category in the provincial level. Also, the calculation of Incremental Capital Output Ratio as the instrument of the efficiency of capital income in North Minahasa Regency in the period of 2013-2017 which is calculated by the standard method to lag0, lagl as well as the mean calculation method, show the result of ICOR which can be categorized as not efficient.
\end{abstract}

Keywords: Analysis of roles, base economic category, efficiency of increment, investment, North Minahasa Regency

\section{ABSTRAK}

Penelitian ini bertujuan untuk menganalisis peranan dari kategori atau sektor ekonomi basis, serta melihat efisiensi dari pertambahan investasi di Kabupaten Minahasa Utara. Penelitian ini dilakukan pada wilayah Kabupaten Minahasa Utara Provinsi Sulawesi Utara. Penelitian ini dimulai pada bulan April sampai bulan Oktober 2018. Penelitian ini menggunakan data sekunder dari Produk Domestik Regional Bruto Atas Dasar Harga Konstan Kabupaten Minahasa Utara dan Provinsi Sulawesi Utara serta data Perubahan Modal Tetap Daerah Bruto Kabupaten Minahasa Utara. Alat analisis yang digunakan dalam penelitian ini, yaitu Location Quotient (LQ), Shift Share Analysis, dan Incremental Capital Output Ratio. Hasil penelitian menunjukkan bahwa nilai LQ menunjukkan kategori pertanian, kehutanan dan perikanan; kategori pertambangan dan penggalian; kategori industri pengolahan; kategori konstruksi; kategori pengadaan listrik dan gas; kategori real estate serta kategori jasa pendidikan merupakan kategori basis di Kabupaten Minahasa Utara, dengan perolehan nilai LQ diatas 1. Peranan kategori basis menunjukkan hasil yang positif terhadap pembentukan Produk Domestik Regional Bruto Kabupaten Minahasa Utara, kategori pertanian kehutanan dan perikanaan merupakan kategori dengan kontribusi terbesar terhadap PDRB Minahasa Utara selama periode 2013-2017. Peranan kategori basis lewat perhitungan regional share (Nij) terhadap Provinsi Sulawesi Utara juga menunjukkan hasil yang positif, artinya kategori basis di Minahasa Utara memberikan kontribusi yang positif terhadap pembentukan PDRB di Provinsi Sulawesi Utara. Pada perhitungan propotional shift (Mij), beberapa kategori basis di Minahasa Utara memperoleh nilai yang negatif, kategori-kategori tersebut adalah kategori pertanian, kehutanan dan perikanan, kategori industri pengolahan, dan kategori jasa pendidikan. Pada perhitungan differential shift (Cij) hanya kategori pengadaan listrik dan gas yang mendapatkan hasil yang negatif atau tidak memiliki daya saing terhadap kategori sejenis pada tingkat provinsi, sementara kategori basis lainnya mendapatkan hasil yang positif atau memiliki keunggulan kompetitif atau daya saing terhadap kategori sejenis pada tingkat Provinsi Sulawesi Utara. Hasil perhitungan Incremental Capital Output Ratio sebagai alat ukur efisiensi masuknya modal di Kabupaten Minahasa Utara pada periode 2013-2017 yang dihitung menggunakan metode standar untuk lag 0 , lag 1 serta metode perhitungan rata-rata, menunjukkan hasil ICOR atau yang tergolong in-efisien.

Kata kunci: Analisis peranan, kategori ekonomi basis, efisiensi pertambahan, investasi, Kabupaten Minahasa Utara

Agrisosioekonomi:

Jurnal Transdisiplin Pertanian (Budidaya Tanaman, Perkebunan, Kehutanan, Peternakan, Perikanan), Sosial dan Ekonomi 


\section{PENDAHULUAN}

\section{Latar Belakang}

Pembangunan ekonomi secara umum bertujuan untuk meningkatkan taraf hidup masyarakat, meningkatkan pendapatan, menjamin tersedianya lapangan pekerjaan serta sebagai pendorong perubahan dan pembaharuan dibidang kehidupan lainnya. Keberhasilan pembangunan ini ditunjang oleh keterkaitan dan dukungan dari berbagai pihak serta peranan dari berbagai lapangan usaha. Dalam proses pembangunan ekonomi, setiap sektor atau lapangan usaha yang menunjang kegiatan ekonomi perlu mendapat perhatian khusus.

Pembangunan ekonomi memiliki arti yang luas, tidak hanya sekedar bagaimana menaikan Produk Domestik Bruto per tahun saja, tetapi juga menyangkut kegiatan-kegiatan yang dilakukan suatu negara untuk mengembangkan kegiatan ekonomi dan taraf hidup masyarakatnya. Pembangunan ekonomi harus dipandang sebagai suatu proses yang saling berkaitan dan saling mempengaruhi antara faktor-faktor yang menyebabkan terjadinya pembangunan (Arsyad, 2005)

Pembangunan wilayah merupakan pembangunan ditujukan untuk masyarakat didalam wilayah tersebut. Pada hakikatnya kinerja pembangunan wilayah dapat diukur dengan beberapa tolok ukur yaitu pertumbuhan Produk Domestik Regional Bruto (PDRB), PDRB per kapita, pemerataan pendapatan atau distribusi pemilikan/penguasaan faktor-faktor produksi, jumlah tenaga kerja yang menganggur atau setengan menganggur, jumlah penduduk miskin (relatif dan absolut), tingkat produktifitas sumberdaya wilayah, dan kualitas lingkungan hidup wilayah (Saragih, 2015).

Era Otonomi Daerah ditandai dengan terbitnya Undang-undang Nomor 32 Tahun 2004 tentang Pemerintahan Daearah dan Undang-undang Nomor 33 Tahun 2004 tentang Perimbangan Keuangan Daerah Pemerintah Pusat dan Daerah. Terbitnya Undangundang tersebut melalui Otonomi Daerah diharapkan akan dapat menghilangkan praktik-praktik sentralistik, yang pada satu sisi dianggap kurang menguntungkan bagi daearah dan penduduk lokal. Lahirnya Otonomi Daerah membuat masing-masing daerah memiliki kewenangan dalam menetapkan sektor ekonomi atau komoditi unggulan yang akan diprioritaskan pengembangannya. Sektor unggulan atau sektor basis (Base Sector) yang dikembangkan akan dapat mendorong sektor perekonomian lainnya untuk dapat berkembang.

Sektor unggulan dapat juga disebut sebagai sektor yang dapat di ekspor ke daerah lain karena kegiatan sektor unggulan menghasilkan produk/ jasa yang mendatangkan uang dari luar wilayah (ekspor) dan perkembangan ekspor dapat menjadi motor penggerak dalam pembangunan ekonomi (Sukirno, 2015). Sumbangan sektor ekspor dalam pembangunan secara langsung meliputi kenaikan dalam jumlah ekspor memungkinkan sesuatu daerah untuk menaikkan jumlah impor, termasuk barang modal yang penting peranannya dalam pembangunan ekonomi; sektor ekspor maka dana pembangunan yang tersedia akan dialirkan ke dalam sektor yang paling efisien, yaitu sektor penghasil barang ekspor, yang mampu bersaing dengan sektor yang sama di tingkat nasional; kegiatan ekspor akan mampu memperluas pasar untuk produksi dalam wilayah dan memungkinkan perluasan skala produksi sektor industri dan selanjutnya menciptakan economies of scale; serta perusahaanperusahaan yang harus tetap mempertahankan kedudukan yang competitive dalam pasar dengan menekan ongkos produksi dan mempertinggi efisiensi kegiatannya.

Kegiatan investasi merupakan bagian dari suatu kegiatan pembangunan karena investasi dapat meningkatkan pertumbuhan ekonomi suatu wilayah. Investasi merupakan kunci dari pertumbuhan ekonomi sebab investasi dapat menciptakan pendapatan dan dapat memperbesar kapasitas produksi perekonomian dengan cara meningkatkan stok modal. Iklim investasi yang baik akan mendorong terjadinya pertumbuhan ekonomi dimana kegiatan investasi akan memperkuat pertumbuhan ekonomi dengan menambah input lebih banyak ke dalam suatu proses produksi. Pengaturan yang baik dari pemerintah daerah dalam merumuskan kebijakan terkait investasi dan dunia usaha akan sangat penting dalam upaya menarik investor untuk dapat berinvestasi di daerahnya (Jhingan, 2010).

Kabupaten Minahasa Utara merupakan salah satu kabupaten yang ada di Provinsi Sulawesi Utara. Kabupaten ini merupakan hasil pemekaran dari Kabupaten Minahasa sesuai dengan keputusan Dewan Perwakilan Rakyat Daearah Provinsi Sulawesi Utara Nomor 7 Tahun 2002 tentang persetujuan dukungan terhadap pembentukan Kabupaten Minahasa Utara kemudian ditetapkan dalam Undang-undang Nomor 33 Tahun 2003 dan diresmikan Menteri Dalam Negeri atas nama Presiden republik Indonesia pada Tanggal 7 Januari 2004.

Kabupaten Minahasa Utara menunjukkan perkembangan diberbagai bidang pembangunan dari tahun ke tahun. Ini ditunjang dengan keberadaan berbagai potensi ekonomi sebagai penggerak pembentukan struktur ekonomi di Kabupaten Minahasa Utara. Kondisi ini belum bisa menggambarkan kinerja, potensi, serta kemampuan sektor-sektor ekonomi dalam pembentukan perekonomian di Kabupaten Minahasa Utara. Hal ini perlu untuk dianalisis untuk melihat kategori atau sektor yang unggul dan berkualitas (leading sector) serta memiliki daya saing dalam proses pembentukan struktur ekonomi di Kabupaten Minahasa utara.

Analisis peranan kategori ekonomi basis dan efisiensi pertambahan in-efisiensi dalam perekonomian di Kabupaten Minahasa Utara perlu dilakukan, hal ini 
sangat penting sebagai acuan dalam melakukan kegiatan perencanaan dan pembangunan daerah agar kebijakan pembangunan perekonomian daerah benar-benar terarah pada sektor-sektor ekonomi unggulan yang menjadi sektor basis dalam perekonomian di Kabupaten Minahasa Utara, seiring dengan hal tersebut diharapkan agar anggaran untuk pembangunan daerah dapat digunakan secara efektif dan efisien serta tepat sasaran dalam pembangunan sektor ekonomi unggulan sehingga diharapkan akan terjadi sinergitas sektoral terhadap sektor-sektor nonbasis dalam upaya meningkatkan kinerja sektorsektor perekonomian di Kabupaten Minahasa Utara.

\section{Perumusan Masalah}

Berdasarkan latar belakang yang sudah diuraikan, maka yang menjadi masalah dalam penelitian ini adalah:

1. Kategori lapangan usaha apa saja yang menjadi unggulan dalam struktur perekonomian di Kabupaten Minahasa Utara?

2. Bagaimana Peranan kategori lapangan usaha di Kabupaten Minahasa Utara?

3. Bagaimana efisiensi pertambahan investasi di Kabupaten Minahasa Utara?

\section{Tujuan Penelitian}

Tujuan dilakukannya penelitian ini adalah:

1. Menganalisis kategori basis apa saja yang ada di Kabupaten Minahasa Utara.

2. Menganalisis peranan kategori basis yang ada di Kabupaten Minahasa Utara.

3. Menganalisis efisiensi pertambahan investasi di Kabupaten Minahasa Utara.

\section{Manfaat Penelitian}

Hasil penelitian ini diharapkan dapat memberikan manfaat untuk :

1. Manfaat Teoritis

Penelitian ini diharapkan dapat memberikan manfaat berupa ilmu pengetahuan di bidang pembangunan daerah, khususnya pembangunan regonal. Diharapkan penelitian ini juga bermanfaat dalam pemecahan masalah pembangunan daerah atau pengembangan suatu kelembagaan.

2. Manfaat Praktis

Secara praktis penelitian ini diharapkan memiliki manfaat sebagai bahan masukan dan sumbangan pemikiran bagi pemerintahan Kabupaten Minahasa utara serta sebagai wawasan dan referensi untuk penelitian bterkait selanjutnya.

\section{METODE PENELITIAN}

Lokasi dan Waktu Penelitian

Penelitian ini dilakukan pada wilayah Kabupaten Minahasa Utara Provinsi Sulawesi Utara. Penelitian ini dimulai pada bulan April 2018 sampai bulan Oktober 2018.

\section{Jenis Data dan Sumber Data}

Penelitian ini menggunakan data sekunder yang diperoleh dari:

1. Badan Pusat Statistik Kabupaten Minahasa Utara dan Badan Pusat Stratistik Provinsi Sulawesi Utara berupa data Produk Dosmestik Regional Bruto Kabupaten Minahasa Utara, data Produk Domestik Regional Bruto Provinsi Sulawesi Utara, data Laju Pertumbuhan Tahun 2013 - 2017.

2. Badan Perencanaan, Pembangunan, Penelitian, dan Pengembangan Daerah Kabupaten Minahasa Utara dan Satuan Kerja Perangkat Daerah lewat instansi terkait berupa data-data tentang perekonomian, sosial, dan keadaan wilayah Kabupaten Minahasa Utara.

\section{Metode Pengumpulan Data.}

Data yang digunakan dalam penelitian ini diperoleh dengan metode mendatangi langsung ke sumber data yakni instansi yang terkait untuk mendapatkan data yang diperlukan. Selain itu, data yang akan diperlukan diperoleh lewat studi kepustakaan dan Searching data melalui Internet.

\section{Definisi Operasional dan Pengukuran Variabel}

Variabel-variabel yang digunakan dalam penelitian ini dapat didefinisikan dan diukur sebagai berikut:

1. Produk Domestik Regional Bruto (PDRB) Atas Dasar Harga Konstan (ADHK)

Provinsi Sulawesi Utara dan Kabupaten Minahasa Utara. Yaitu keseluruhan nilai tambah bruto yang dihitung berdasarkan harga barang dan jasa pada tahun dasar. Variabel ini diukur dalam jumlah nominal rupiah. Data PDRB yang digunakan yaitu dari Tahun $2013-2017$.

2. Kategori basis dalam perekonomian Kabupaten Minahasa Utara.

Kategori atau sektor basis adalah sektor yang menjadi unggulan perekonomian daerah karena mempunyai keuntungan kompetitif yang cukup tinggi. Sedangkan sektor nonbasis adalah sektor yang kurang potensial tetapi berfungsi sebagai penunjang sektor basis. Untuk mengetahui sektor ekonomi basis maka digunakan analisis Location Quotient, jika didapatkan sektor tertentu memiliki nilai $\mathrm{LG}>1$ maka sektor tersebut merupakan sektor basis dan sebaliknya jika sektor tertentu memiliki nilai LQ $<1$ maka sektor tersebut bukan merupakan sektor basis. 
3. Laju Pertumbuhan Ekonomi

Laju pertumbuhan ekonomi adalah kenaikan PDRB tanpa memandang apakah kenaikan itu lebih besar atau lebih kecil dari pertumbuhan penduduk, atau apakah perubahan struktur ekonomi berlaku atau tidak. Laju pertumbuhan ekonomi diukur dengan indikator perkembangan PDRB dari tahun ke tahun yang dinyatakan dalam persen per tahun. Analisis ini digunakan untuk mengetahui pembangunan daerah dilihat dari besarnya pertumbuhan PDRB setiap tahunnya di Provinsi Sulawesi Utara dan Kabupaten Minahasa Utara.

4. Komponen Regional Share (Nij) atau komponen pertumbuhan wilayah.

Untuk menentukan sejauh mana perkembangan dan pertumbuhan yang terjadi pada sektor-sektor perekonomian Kabupaten Minahasa Utara akibat pengaruh kegiatan pada sektor-sektor ekonomi yang sama dalam perekonomian Provinsi Sulawesi Utara.

5. Komponen propotional shift (Mij)

Untuk mengukur perubahan relatif atau penurunan pada daerah dibandingkan dengan perekonomian yang lebih besar yang dijadikan acuan. Pengukuran ini bertujuan apakan perekonomian daerahterkonsentrasi pada sektor atau industri yang tumbuh lebih cepat ketimbang perekonomian yang dijadikan acuan. Komponen pengukuran ini biasa juga disebut dengan bauran industri atau Industrial mix dimana juka hasilnya positif berarti sektor perekonomian di daerah tersebut tumbuh lebih cepat dibandingkan perekonomian yang ada diatasnya yang dijadikan acuan, demikian pula jika sebaliknya.

6. Komponen differential shift (Cij)

Untuk menentukan seberapa jauh daya saing sektor atau industri daerah dengan perekonomian yang dijadikan acuan. Jika pergeseran diferensial dari suatu sektor atau industri adalah positif maka sektor atau industri tersebut memiliki daya saing yang lebih tinggi terhadap sektor atau industri yang sama pada perekonomian yang dijadikan acuan.

7. Investasi

Investasi adalah pengeluaran yang ditujukan untuk meningkatkan atau mempertahankan stok barang modal dalam suatu produksi untuk meningkatkan output produksi. Investasi sektor ekonomi yang dimaksudkan dalam variabel ini adalah suatu bentuk investasi yang dilakukan oleh masyarakat dalam sektor ekonomi dan pemerintah Kabupaten Minahasa Utara, dimana modal/dana yang digunakan oleh masyarakat dalam sektor ekonomi untuk melakukan investasi berasal dari pinjaman perbankan baik dalam bentuk rupiah maupun valuta asing meliputi pinjaman yang digunakan sebagai investasi dan modal kerja.
Perhitungan ICOR menggunakan konsep investasi ekonomi nasional. Pengertian investasi yang dimaksud disini adalah fixed capital formation, atau pembentukan barang modal tetap yang terdiri dari tanah, gedung/konstruksi, mesin berikut perlengkapannya, kendaraan, dan barang modal lainnya, dalam hal ini yang dimaksud adalah Pembentukan Modal Tetap Bruto (PMBT) daerah Kabupaten Minahasa Utara.

\section{Metode Analisis Data}

Dalam penelitian ini metode yang digunakan adalah metode analisa kuantitatif melalui pendekatan basis ekonomi. Untuk menjawab permasalahan dalam penelitian ini, maka ditetapkan beberapa metode analisis data, yaitu :

1. Analisis Deskriptif Kuantitatif

Metode ini berupa metode analisa secara verbal dan kuantitatif, baik dengan Tabel yang berisi angka-angka maupun dengan menggunakan grafik atau diagram, tujuannya untuk mengkaji dan menganalisa perkembangan yang terjadi dalam perekonomian maupun keadaan sosial masyarakat dan wilayah di Kabupaten Minahasa Utara.

2. Kontribusi sektor-sektor ekonomi terhadap PDRB Kabupaten Minahasa Utara.

Dalam penelitian ini digunakan data PDRB

ADHK tahun 2010 dengan rumus:

$$
\text { Kontribusi }=\frac{\text { Nilai PDRB sektor }-i}{\text { Total PDRB }} \times 100 \%
$$

3. Analisis Location Quotient (LQ)

Analisis Location Quotient (LQ) digunakan untuk mengidentifikasi sektor maupun sub sektor di kabupaten Minahasa Utara. Besarnya nilai LQ dapat diperoleh dari persamaan sebagai berikut:

$$
\mathrm{LQ}=\frac{v i / v t}{v i / v t}
$$

Keterangan :

\section{LQ: Nilai Location Quotient}

vi: PDRB sektor i wilayah Kabupaten Minahasa Utara vt: PDRB total wilayah Kabupaten Minahasa Utara Vi: PDRB sektor i wilayah Provinsi Sulawesi Utara Vt: PDRB total wilayah Provinsi Sulawesi Utara

Hasil perhitungan dengan metode LQ mengandung interpretasi sebagai berikut:

a. Jika LQ > 1, berarti peranan sektor i di Kabupaten Minahasa Utara lebih menonjol dari pada peranan sektor yang sama pada provinsi Sulawesi Utara, sehingga sektor i merupakan sektor basis atau sektor unggulan bagi kabupaten Minahasa Utara dan menunjukkan bahwa Kabupaten Minahasa Utara memiliki keunggulang Komparatif untuk sektor i yang dimaksud sehingga dapat menjadi prioritas utama dalam perencanaan pembangunan di Kabupaten Minahasa Utara. 
b. Jika LQ $<1$, berarti perananan sektor i di Kabupten Minahasa Utara lebih kecil dari pada peranan sektor yang sama pada tingkat Provinsi Sulawesi Utara Sehingga sektor i tersebut bukan sebagai sektor basis bagi Kabupaten Minahasa Utara, sehingga hanya mampu melayani perekonomian secara lokal di dalam lingkup lokal perekonomian wilayah Kabupaten Minahasa Utara.

c. Jika $L Q=1$, berarti peranan sektor i di Kabupaten Minahasa Utara adalah sama dengan peranan sektor i pada tingkat Provinsi Sulawesi Utara, sehingga jika sektor i yang dimaksud hendak diprioritaskan juga dalam rencana pembangunan di Kabupaten Minahasa Utara maka Kontribusinya akan sama atau stagnan terhadap perkembangan perekonomian Kabupaten Minahasa utara. oleh karena itu, jika hasil dari pengembangan suatu sektor perekonomian tidak memberikan peningkatan daya saing sektor yang dimaksud terhadap perekonomian yang lebih tinggi diatasnya, maka sebaiknya sektor tersebut tidak menjadi prioritas dalam rencana pembangunan perekonomian wilayah.

4. Analisis Shift Share

Analisis Shift Share digunakan untuk mengetahui perubahan dan pergeseran sektor perekonomian wilayah Kabupaten Minahasa Utara. metode Shift share bertujuan untuk mengkaji daya saing dari sektor-sektor ekonomi yang ada di Kabupaten Minahasa Utara Terhadap Perekonomian Provinsi Sulawesi Utara serta perubahan struktur perekonomian Kabupaten Minahasa Utara akibat pengaruh kegiatan ekonomi Provinsi Sulawesi Utara. Data yang digunakan dalam analisis Shift Share ini ialah PDRB Kabupaten Minahasa Utara dan Provinsi Sulawesi Utara tahun 2013-2017 menurut lapangan usaha atas dasar harga konstan tahun 2010.

Rumus yang digunakan dalam analisis shift share adalah sebagai berikut:

$$
\begin{array}{ll}
\mathrm{Dij} & =\mathrm{Nij}+\mathrm{Mij}+\mathrm{Cij} \\
\mathrm{Nij} & =Y i j \cdot r n \\
\mathrm{Mij} & =Y i j(\text { rin-rn) } \\
\mathrm{Cij} & =Y i j(\text { rij-rin) }
\end{array}
$$

Keterangan :

Dij : Pergeseran (selisih) PDRB total sektor i di wilayah j Kabupaten Minahasa utara

Nij : Komponen pertumbuhan regional total sektor i di wilayah j Kabupaten Minahasa Utara

Mij : Komponen pertumbuhan proposional total sektor i di wilayah j kabupaten Minahasa Utara

Cij : Komponen Keunggulan kompetitif total sektor i di wilayah j Kabupaten Minahasa Utara.

Yij : PDRB total sektor i di wilayah Kabupaten Minahasa Utara

Yin : PDRB total sektor i di wilayah n Provinsi Sulawesi utara rn : laju pertumbuhan keseluruhan pada wilayah $\mathrm{n}$ Provinsi Sulawesi Utara

rin : laju pertumbuhan sektor i pada wilayah n Provinsi Sulawesi utara

Rij : laju pertumbuhan sektor i pada wilayah j Kabupaten Minahasa Utara

5. Incremental Capital-Output Ratio (ICOR) Incremental Capital Output Ratio (ICOR) adalah suatu besaran yang menunjukkan besarnya tambahan capital (investasi) baru yang dibutuhkan untuk menaikkan/menambah satu unit output. Besaran ICOR diperoleh dengan membandingkan besarnya tambahan kapital dengan tambahan output. Karena unit kapital bentuknya berbeda-beda dan beraneka ragam sementara unit output relatif tidak berbeda, maka untuk memudahkan penghitungan keduanya dinilai dalam bentuk uang (nominal).

ICOR merupakan suatu hubungan antara investasi yang ditanamkan dan pendapatan tahunan yang dihasilkan dari investasi tersebut. Pentingnya ICOR ini akan tampak ketika diuji konsistensinya antara target pertumbuhan ekonomi dengan tambahan modal yang mungkin akan terkumpul dari investasi yang sedang berjalan (Widodo, 2006). Dengan demikian, ICOR dapat dipakai untuk menentukan laju pertumbuhan suatu perekonomian. Konsep ICOR bersifat dinamis karena menunjukkan perubahan kenaikan/ penambahan output sebagai akibat langsung dari penambahan capital. ICOR bisa diformulasikan sebagai berikut:

Dimana:

$$
\mathrm{ICOR}=\Delta \mathrm{K} / \Delta \mathrm{Y}
$$

$\Delta \mathrm{K} \quad$ : Perubahan Kapital

$\Delta \mathrm{Y} \quad$ : Perubahan Output

Dari rumus tersebut didapatkan pengertian bahwa ICOR merupakan statistik yang menunjukkan kebutuhan perubahan stok kapital untuk menaikan satu unit output. Dalam perkembangannya, data yang digunakan untuk menghitung ICOR bukan lagi hanya penambahan barang modal atau perubahan stok kapital melainkan investasi (I) yang ditanamkan oleh swasta maupun pemerintah sehingga rumusan ICOR dimodifikasi menjadi :

$$
\mathrm{ICOR}=\mathrm{I} / \Delta \mathrm{Y}
$$

Keterangan :

I : Investasi

$\Delta \mathrm{Y}$ : Perubahan Output

Rumus ini disebut dengan Gross ICOR, yaitu suatu rasio yang menunjukkan besarnya tambahan unit kapital yang diperlukan untuk memperoleh tambahan satu unit output pada suatu periode tertentu. Dalam 
penerapannya rumus Gross ICOR ini lebih sering dipakai karena data yang digunakan tersedia relatif lebih lengkap (Badan Pusat Statistik DIY, 2013). Dalam beberapa hal untuk kasus-kasus tertentu, investasi yang ditanamkan pada suatu tahun akan langsung menghasilkan tambahan output pada tahun itu juga (lag 0), sehingga rumus di atas dapat dinyatakan sebagai berikut (Badan Pusat Statistik DIY, 2013).

Keterangan :

$$
I C O R=\frac{I t}{\left(Y t-Y t_{-1}\right)}
$$

$\mathrm{I}=$ Investasi / PMTDB pada tahun ke-t

$\mathrm{Yt}=$ Output pada tahun ke $\mathrm{t}$

Yt-1 =Output pada tahun ke-(t-1)

Untuk menghitung nilai ICOR lag 1 rumus yang digunakan adalah sebagai berikut :

Keterangan :

$$
I C O R=\frac{I t}{\left(Y t_{+1}-Y t\right)}
$$

$\mathrm{I}=$ Investasi / PMTDB pada tahun ke-t

$\mathrm{Yt}=$ Output pada tahun ke $\mathrm{t}$

$\mathrm{Yt}+1=$ Output pada tahun ke-(t+1)

Pada metode standar, langkah penghitungan dilakukan terlebih dahulu dengan mencari ICOR pada masing-masing tahun untuk periode waktu $t_{1}$ sampai $t_{n}$, sehingga akan didapatkan nilai ICOR sebanyak n buah. ICOR yang dianggap dapat mewakili untuk periode waktu tersebut $\left(\mathrm{t}_{1} \mathrm{~s} . \mathrm{d}_{\mathrm{n}}\right)$ diperoleh dengan jalan membagi antara jumlah nilai ICOR selama periode waktu $t_{1}$ s.d $t_{n}$ dengan jumlah tahun (n), atau dengan mencari rata-rata nilai ICOR selama periode $t_{1}$ sampai dengan $t_{n}$. Prinsip dari penghitungan ICOR metode standar ini adalah rata-rata sederhana dan penulisannya secara matematis sebagai berikut:

$$
\operatorname{ICOR}=\frac{1}{n} \sum \frac{I t}{Y t-Y t_{-1}}
$$

Keterangan :

It = Investasi / PMTDB pada tahun ke-t

$\mathrm{Yt}=$ Output pada tahun ke $\mathrm{t}$

Yt-1 =Output pada tahun ke-(t-1)

$\mathrm{n}=$ jumlah data yang dianalisis.

\section{HASIL DAN PEMBAHASAN}

\section{Gambaran Umum Lokasi Penelitian}

Minahasa Utara adalah salah satu Kabupaten yang berada di Provinsi Sulawesi Utara, merupakan daerah otonom hasil pemekaran dari Kabupaten Minahasa melalui Undang-undang Nomor 33 Tahun 2003 dan diresmikan pada tanggal 7 Januari 2004. Kabupaten ini memiliki lokasi yang strategis karena berada diantara dua kota, yaitu Ibu kota Provinsi Sulawesi Utara Manado dan kota pelabuhan Bitung dengan batas-batas wilayah: sebelah utara berbatasan dengan Kabupaten Kepulauan Sitaro, Laut Sulawesi serta Laut Maluku, sebelah timur berbatasan dengan Kota Bitung, sebelah selatan berbatasan dengan Kabupaten Minahasa, dan sebelah barat berbatasan dengan Kota Manado.

Kabupaten Minahasa Utara terletak pada kordinat antara $1^{\circ} 18^{\prime} 30^{\prime}-1^{\circ} 53^{\prime} 00^{\prime}$ Lintang Utara dan $124^{\circ} 44^{\prime} 00^{\prime}$ '- $125^{\circ} 11^{\prime} 00^{\prime}$ ' Bujur Timur. Luas Kabupaten Minahasa Utara adalah 1.059,24 km2 dengan sebagian besar daerah yang memiliki topografi berbukit-bukit dan lereng, diantaranya terdapat Gunung Klabat dengan tinggi 1.995 meter diatas permukaan laut (MDPL) yang merupakan gunung tertinggi di Provinsi Sulawesi Utara. Berdasarkan pembagian wilayah administratif, Kabupaten Minahasa Utara dibagi dalam 10 Kecamatan yaitu kecamatan : Kema, Kauditan, Airmadidi, Kalawat, Dimembe, Talawaan, Wori, Likupang Barat, Likupang Timur, Likupang Selatan, serta memiliki 135 desa/ kelurahan dirinci 125 desa dan 6 kelurahan.

Tabel 1. Luas Wilayah Menurut Kecamatan di Kabupaten Minahasa Utara, 2015

\begin{tabular}{lrrr}
\hline KECAMATAN & $\begin{array}{r}\text { JUMLAH DESA/ } \\
\text { KELURAHAN }\end{array}$ & $\begin{array}{r}\text { JUMLAH } \\
\text { JAGA }\end{array}$ & $\begin{array}{r}\text { LUAS } \\
\left(\mathbf{K M}^{\mathbf{2}}\right)\end{array}$ \\
\hline Kema & 11 Desa & 73 & 78,76 \\
Kauditan & 12 Desa & 133 & 108,20 \\
Airmadidi & 3 Desa & & \\
& 6 Kelurahan & 81 & 86,66 \\
Kalawat & 12 Desa & 100 & 39,03 \\
Dimembe & 11 Desa & 83 & 166,43 \\
Talawaan & 12 Desa & 80 & 82,51 \\
Wori & 19 Desa & 129 & 90,7 \\
Likupang Barat & 20 Desa & 89 & 104,29 \\
Likupang Timur & 18 Desa & 82 & 290,84 \\
Likupang Selatan & 7 Desa & 32 & 11,82 \\
\hline Jumlah / Total & 125 Desa & 823 & $1.059,24$ \\
& 6 Kelurahan & & \\
\hline Sumber : Badan Put
\end{tabular}

Sumber : Badan Pusat Statistik Minahasa Utara, 2017

Tabel 1 menunjukkan bahwa Kecamatan yang paling luas wilayahnya adalah Kecamatan Likupang Timur yaitu dengan luas 290,84 Km2 atau mencakup $27,46 \%$ total wilayah Kabupaten Minahasa Utara.

\section{Keadaan Topografi}

Kondisi wilayah Kabupaten Minahasa Utara terdiri dari pegunungan, berbukit dan daerah dataran rendah, yang secara rinci dibagi menjadi beberapa bagian yaitu :

a. Bagian Selatan terdiri dari dataran rendah berbukit dengan ketinggian berkisar pada 100 meter sampai 650 meter yang membentang sepanjang Kecamatan Kalawat dan Airmadidi dan Bagian Tengah terdiri dari perbukitan dan pegunungan dengan ketinggian berkisar pada 150 meter sampai 650 meter kecuali Gunung Klabat dan sekitarnya yang mencapai ketinggian kurang lebih 1995 meter dan dataran ini membentang dari Kecamatan Dimembe, Kecamatan Airmadidi dan Kecamatan Kauditan. 
b. Bagian Utara, Timur dan Barat terdiri dari dataran rendah yang tanahnya kurang subur dengan ketinggian 2 meter sampai 10 meter, daerah ini membentang sepanjang Pantai Timur ke Utara sampai Barat dari Kecamatan Kema, Likupang Timur, Likupang Barat, Wori.

c. Karakter permukaan tanah hampir sama di semua wilayah kecamatan dan dapat dikategorikan: Datar, Landai dan Bergelombang dengan kemiringan tanah: antara $0-3^{\circ}$ sekitar $30,49 \%$, kemiringan tanah antara $3-15^{\circ}$ adalah sekitar 30,49\%, kemiringan antara 15 $45^{\circ}$ sekitar $19,66 \%$ dan kemiringan tanah diatas $45^{\circ}$ adalah sekitar $6,43 \%$. Kedalaman tanah efektif rata-rata $0-5 \mathrm{~m}$ dengan tingkat keasaman (ph) antara 6,0-8,0 serta memiliki tekstur tanah yang bervariasi mulai dari tanah liat (alluvial), tanah liat berpasir (latosol), tanah liat berlempung (meditrean) dan tanah lempung berpasir (regosol).

\section{Keadaan Kependudukan}

Penduduk Kabupaten Minahasa Utara berdasarkan proyeksi penduduk tahun 2016 berjumlah 199.498 jiwa, yang terdiri atas 101.270 jiwa penduduk laki-laki dan 98.228 jiwa penduduk perempuan dengan rasio sebesar 103,10 penduduk laki-laki terhadap penduduk perempuan. Dibandingkan dengan proyeksi tahun 2015, penduduk Minahasa Utara mengalami pertumbuhan sebesar 0,71 persen. Pertumbuhan rata-rata jumlah penduduk di Kabupaten Minahasa Utara sejak tahun 2014 hingga 2016 adalah 0,77 persen pertahun, dengan pertambahan rata-rata 1.539 jiwa pertahun.

Tabel 2. Jumlah Penduduk Minahasa Utara menurut Kecamatan

\begin{tabular}{|c|c|c|c|}
\hline Kecamatan & 2014 & 2015 & 2016 \\
\hline Kema & 16.205 & 16.486 & 16.746 \\
\hline Kauditan & 24.263 & 24.383 & 24.467 \\
\hline Airmadidi & 28.153 & 28.512 & 28.833 \\
\hline Kalawat & 29.743 & 30.499 & 31.225 \\
\hline Dimembe & 23.568 & 23.729 & 23.855 \\
\hline Talawaan & 19.932 & 20.493 & 21.038 \\
\hline Wori & 17.288 & 17.096 & 16.876 \\
\hline Likupang Barat & 16.404 & 16.238 & 16.046 \\
\hline Likupang Timur & 15.905 & 15.733 & 15.540 \\
\hline Likupang Selatan & 5.103 & 4.915 & 4.866 \\
\hline Jumlah / Total & 196.419 & 198.084 & 199.498 \\
\hline
\end{tabular}

Tabel 2 menunjukkan data kependudukan kecamatan yang memiliki jumlah penduduk terbanyak di Kabupaten Minahasa Utara tahun 2016 adalah Kecamatan Kalawat dengan jumlah penduduk mencapai 31.225 jiwa. Kecamatan Airmadidi menempati urutan kedua sebagai wilayah yang memiliki jumlah penduduk terbanyak dengan jumlah 28.833 jiwa. Kecamatan Airmadidi dan Kecamatan Kalawat merupakan kawasan sentra perekonomian, perdagangan, dan pusat pendidikan tinggi sehingga membuat banyak pendatang dari kecamatan sekitarnya bahkan luar Kabupaten Minahasa Utara tinggal dan menetap di wilayah ini. Kecamatan yang memiliki jumlah penduduk paling sedikit adalah Kecamatan Likupang Selatan dengan jumlah penduduk 4.866 jiwa, kecamatan ini merupakan pemekaran dari Kecamatan Likupang Timur.

\section{Ketenagakerjaan}

Berdasarkan data ketenagakerjaan hasil survei angkatan kerja nasional tahun 2015, tercatat jumlah penduduk Kabupaten Minahasa Utara usia kerja (15 tahun ke atas) sebanyak 146.692 jiwa dimana 81.587 jiwa termasuk angkatan kerja. 73.360 Jiwa yang bekerja dan 8.227 Jiwa merupakan pengangguran terbuka. Jumlah penduduk yang bukan angkatan kerja adalah 65.105 dengan rincian yang sedang bersekolah 14.609 Jiwa, mengurus rumah tangga 40.178 jiwa dan yang berada dalam kegiatan lainnya adalah 10.318 jiwa. Jumlah penduduk yang bekerja menurut lapangan pekerjaan utama tahun 2015 sebagai berikut:

a. Pertanian, Perkebunan, Kehutanan, Perburuan, dan Perikanan sebanyak 23.740 jiwa.

b. Industri (Pertambangan, Industri, Konstruksi, Listrik, Gas, dan Air) sebanyak 14.482 jiwa.

c. Jasa (Perdagangan, Rumah Makan dan Jasa Akomodasi, Lembaga Keuangan, Real Estate, Usaha Persewaan dan Jasa Perusahaan, Jasa Kemasyarakatan, Sosial, dan Perorangan) sebanyak 35.138 jiwa.

\section{Bidang Pendidikan}

Sektor pendidikaan menjadi pilar penting dalam proses peningkatan kualitas hidup sumber daya manusia. Pendidikan merupakan salah satu faktor yang sangat penting dalam hidup bermasyarakat, selain untuk meningkatkan kesejahteraan hidup, juga pendidikan memiliki efek positif pada kehidupan bermasyarakat, dimana setiap orang yang dibentuk karakternya lewat pendidikan diharapkan akan dapat memahami pula tugas-tugasnya sebagai warga negara yang baik. Penduduk Kabupaten Minahasa Utara menurut jenis pendidikan dapat dilihat pada Tabel 3. 
Tabel 3. Jumlah Penduduk Menurut Tingkat Pendidikan Kabupaten Minahasa Utara Tahun 2017

\begin{tabular}{llrr}
\hline No. & Tingkat Pendidikan & $\begin{array}{r}\text { Jumlah } \\
\text { Tahun 2016 }\end{array}$ & $\begin{array}{r}\text { Jumlah Tahun } \\
\mathbf{2 0 1 7}\end{array}$ \\
\hline 1. & Tidak/Belum Sekolah & 27.753 & 29.702 \\
2. & Tidak Tamat SD/Sederajat & 26.667 & 26.474 \\
3. & Tamat SD/Sederajat & 44.533 & 43.299 \\
4. & SLTP/Sederajat & 34.911 & 34.548 \\
5. & SLTA/Sederajat & 69.813 & 71.129 \\
6. & Diploma I/IIS & 1.147 & 1.043 \\
7. & Akademi/Diploma III/S.Muda & 2.388 & 2.415 \\
8. & Diploma IV/Strata I & 8.763 & 9.373 \\
9. & Strata II & 753 & 804 \\
10. & Strata III & 70 & 86 \\
\hline \multicolumn{2}{r}{ Total } & 216.798 \\
\hline Sumber: Badan Pusat Statistik Minahasa Utara, 2017
\end{tabular}

Sumber: Badan Pusat Statistik Minahasa Utara, 2017

Sampai tahun 2017, Kabupaten Minahasa Utara memiliki 230 bangunan Pendidikan Anak Usia Dini (PAUD), 171 Taman Kanak-kanak (TK), 1.285 SD/MI/Sederajat, 404 SMP/MTS/ Sederajat, dengan jumlah tenaga pengajar sebanyak 2.692 orang dan Siswa sebanyak 34.007 orang. Menurut jumlah siswa, guru dan bangunan sekolah Kabupaten dapat dilihat pada Tabel 4.

Tabel 4. Jumlah Siswa, Guru dan Bangunan Sekolah Kabupaten Minahasa Utara Tahun 2017

\begin{tabular}{lrrr}
\hline URAIAN & \multicolumn{3}{c}{ JUMLAH } \\
& SISWA & GURU & BANGUNAN \\
\hline PAUD & 1.004 & 98 & 230 \\
TK & 2.268 & 256 & 171 \\
SD/MI/Sederajat & 21.197 & 1.005 & 1.285 \\
SMP/MTS/Sederajat & 9.538 & 461 & 404 \\
\hline Jumlah & 34.007 & 1.820 & 2.90 \\
\hline
\end{tabular}

Sumber : Badan Pusat Statistik Minahasa Utara, 2017

\section{Indeks Pembangunan Manusia (IPM)}

Pembangunan daerah hendaknya tidak hanya berorientasi kepada pencapaian pertumbuhan ekonomi yang tinggi semata, namun setidaknya pencapaian pembangunan juga harus mampu dirasakan manfaatnya dan menjawab kebutuhan masyarakat.

Salah satu indikator keberhasilan pembangunanterhadap masyarakat adalah indikator Indeks Pembangunan Manusia (IPM). Pencapaian IPM Kabupaten Minahasa Utara meningkat dari tahun 2014 sebesar 70,09 menjadi 71,09 di tahun 2015 sampai 71,49 di tahun 2016.

\section{Bidang Ekonomi}

Kinerja pembangunan daerah salah satunya diukur dari pertumbuhan ekonomi yaitu dengan menggunakan pemngamatan terhadap nilai Produk Domestik Regional Bruto (PDRB). Laju pertumbuhan menurut Produk Domestik Regional Bruto Atas Dasar Harga Konstan Kabupaten Minahasa Utara berada pada angka $7,45 \%$ tahun 2014, 7,09\% pada tahun 2015, dan $7.06 \%$ pada tahun 2016 . a. Pertumbuhan Ekonomi

Menurut kategori lapangan usaha, pertumbuhan lapangan usaha di Kabupaten Minahasa Utara tahun 2012-2016 bervariasi. Pada tahun 2012 lapangan usaha dengan pertumbuhan paling tinggi adalah pengadaan listrik dan gas dengan pertumbuhan sebesar 11,62\% kemudian diikuti lapangan usaha Jasa Keuangan dan Asuransi dan Administrasi Pemerintahan, Pertahanan dan Jaminan Sosial Wajib dengan pertumbuhan ekonomi masing-masing sebesar 9,57\% dan 9,32\%. Pada tahun 2013, tiga lapangan usaha dengan pertumbuhan ekonomi tertinggi di Kabupaten Minahasa Utara adalah Pengadaan Listrik dan Gas, (15,59\%), Penyediaan Akomodasi dan Makan Minum (10,01\%), dan Informasi Komunikasi (9,21\%. Pada tahun 2016 lapangan usaha yang memiliki pertumbuhan tertinggi adalah Jasa Keuangan dan Asuransi sebesar (23,06\%), Pengadaan Listrik dan Gas sebesar $(14,98 \%)$ dan Penyediaan Akomodasi dan Makan Minum sebesar $(12,56 \%)$.

b. Pendapatan Perkapita

Produk Domestik Regional Bruto (PDRB) Perkapita adalah ukuran produktivitas dari faktorfaktor produksi dalam suatu wilayah untuk melakukan transformasi berbagai sumber daya alam, sumber daya manusia, dan sumber daya finansial dalam proses produksi sehingga dapat menghasilkan sejumlah pendapatan dimana pendapatan tersebut belum tentu seluruhnya diterima dan dinikmati masyarakat suatu wilayah tersebut. PDRB perkapita secara kasar dapat digunakan sebagai proxi indikator pendapatan perkapita yang mencerminkan pendapatan rata-rata setiap individu di suatu wilayah sekaligus merupakan salah satu indikator yang dapat digunakan untuk menggambarkan tingkat kemakmuran masyarakat secara makro.

Semakin tinggi pendapatan yang diterima penduduk di suatu wilayah, maka tingkat kesejahteraan penduduk di wilayah tersebut dapat dikatakan bertambah baik. Angka PDRB perkapita Kabupaten Minahasa Utara Atas Dasar Harga Berlaku tumbuh sekitar 9-14 persen per tahun pada periode 2012-2016 yang ditunjukan dengan adanya kenaikan yang terus menerus tiap tahun dari 38,94 juta rupiah di tahun 2012 menjadi 52,07 juta rupiah di tahun 2016. Sementara jika dilihat berdasarkan PDRB Atas Dasar Harga Konstan, yang tidak mempertimbangkan laju inflasi, pertumbuhan PDRB perkapita Kabupaten Minahasa Utara pada periode 2012-2016 relatif lebih lambat, yaitu hanya sebesar 5-7 persen. Pada tahun 2012, PDRB perkapita Kabupaten Minahasa Utara masih sebesar 30,6 juta rupiah, kemudian meningkat perlahan menjadi 38 juta rupiah pada tahun 2016. 
Kondisi tersebut menjelaskan bahwa walaupun secara nominal PDRB perkapita mengalami peningkatan yang cukup tinggi, tetapi secara riil PDRB perkapita tidak mengalami perubahan yang signifikan selama periode 20122016. Peningkatan pertumbuhan ekonomi Kabupaten Minahasa Utara tidak terlepas dari pertumbuhan kinerja sektor/kategori yang dominan, yakni sektor pertanian, sektor perdagangan hotel/restoran dan sektor pertambangan yang diikuti oleh sektor-sektor/ kategori lainnya (Badan Pusat Satatistik, 2017).

\section{Pemerintahan Kabupaten Minahasa Utara}

Berpijak pada Visi Rencana Pembangunan Jangka Panjang Daerah (RPJPD) Kabupaten Minahasa Utara Tahun 2005-2025 sebagaimana telah diamanatkan dalam Peraturan Daerah Nomor 3 Tahun 2011 adalah "Terwujudnya Kabupaten Minahasa Utara Yang Harmonis Berbasis Agribisnis, Industri, Pariwisata Yang Berwawasan Lingkungan, Berdaya Saing Untuk Kesejahteraan Dan Kemandirian Masyarakat".

Berpedoman pada arah pembangunan daerah sebagaimana termuat dalam RPJPD Kabupaten Minahasa Utara tahun 2005-2025 tersebut, dan berbagai capaian pembangunan, potensi serta isu-isu strategis, serta tantangan kabupaten Minahasa Utara untuk lima tahun kedepan, maka Bupati dan Wakil Bupati Minahasa Utara terpilih periode tahun 20162021 menetapkan Visi pembangunan yaitu "Minahasa Utara menjadi kabupaten agribisnis, industri dan pariwisata secara terpadu serta berkelanjutan di tahun 2021" (LKPJ Minahasa Utara, 2017).

1. Kabupaten Agribisnis

Kegiatan agribisnis yang bernilai tinggi dan unggul, yang dikembangkan berdasarkan kultur bisnis yang unggul, kelembagaan bisnis yang produktif dan efisien, dan teknologi yang terusmenerus dikembangkan, menuju transformasi struktur ekonomi yang sehat dan dinamis. Transformasi struktur ekonomi adalah syarat untuk membangun ekonomi wilayah yang tangguh, dinamis, dan mensejahterakan, dalam konteks ini pendekatan sistem agribisnis akan mampu merealisasikan transformasi ekonomi yang sehat dan dinamis, karena pengembangan sistem agribisnis mencakup pergeseran peran relatif dari sektor primer, sekunder, hingga tersier, dengan pengembangan ekonomi bersistem agribisnis, transformasi struktur ekonomi dengan sendirinya ikut terpacu.

2. Kabupaten Industri

Kegiatan ekonomi yang mengolah bahan mentah, bahan baku, barang setengah jadi, dan barang jadi menjadi barang dengan nilai tambah yang lebih tinggi penggunaannya. Kegiatan industri di Kabupaten Minahasa Utara seperti pengolahan kelapa dan buah pala serta industri rumah tangga yang memanfaatkan bahan baku komoditi pertanian dan non pertanian masih belum optimal sehingga perlu menjadi perhatian dan sangat berpotensi untuk dikembangkan di masa yang akan datang.

3. Kabupaten Pariwisata

Kabupaten Minahasa Utara memiliki beberapa lokasi objek wisata yang berpotensi dan bernilai jual tinggi. Objek-objek wisata tersebut berupa objek wisata alam, seperti: daerah pegunungan, pantai, pulau, air terjun, danau dan sebagainya, objek wisata budaya yang berupa peninggalan sejarah atau benda-benda purbakala, seperti: Waruga, Penjara tua, Goa Jepang dan agrowisata berbasis ekowisata. Keberadaan objekobjek wisata tersebut sangat disayangkan belum dapat diolah secara optimal untuk menjadi industri wisata yang handal, hal ini terlihat dari pengelolaan yang belum maksimal sehingga berpengaruh terhadap jumlah pengunjung yang datang ke destinasi wisata tersebut.

4. Pembangunan Terpadu dan Berkelanjutan

Pembangunan terintegrasi yang berbasis pada dimensi ekologi, sosial ekonomi dan tata kelola (Governance) yang baik. Sebagai daerah yang menitikberatkan mata pencarian pada sumber daya alam, maka sewajarnya dimensi ekologi adalah dimensi prioritas dari pembangunan berkelanjutan.

Mewujudkan Visi pembangunan Kabupaten Minahasa Utara tahun 2016-2021 yakni "Minahasa Utara menjadi kabupaten agribisnis, industri dan pariwisata secara terpadu serta berkelanjutan di tahun 2021" maka ada tujuh Misi yang disusun untuk memberikan kerangka bagi tujuan dan sasaran serta arah kebijakan yang ingin dicapai dan menentukan jalan yang akan ditempuh untuk mencapai Visi. Berdasarkan visi, misi dan isu-isu strategis yang ada, maka ditetapkan tujuan yang hendak dicapai dalam kurun waktu 5 tahun adalah sebagai berikut:

a. Misi Pertama, Mengembangkan agribisnis secara efisien dan efektif, bertujuan: Mengoptimalkan pemanfaatan potensi pertanian dalam arti luas yang menopang perekonomian daerah, dengan sasaran: Meningkatnya daya saing produk pertanian dan meningkatnya produksi dan produktifitas pertanian.

b. Misi Kedua, Mewujudkan kawasan industri yang berwawasan lingkungan (KABIMA dan Likupang Raya), bertujuan: Meningkatkan industri menopang perekonomian daerah, dengan sasaran: Berkembangnya industri kecil dan menengah; Meningkatnya sarana dan prasarana kawasan industri; iii. 
Meningkatnya kualitas pelayanan perijinan; Meningkatkan dukungan koperasi, usaha kecil dan menengah bagi pengembangan industri, dengan sasaran Meningkatnya produktifitas KUKM.; Meningkatkan pengendalian dan pengawasan pembangunan yang berwawasan lingkungan, dengan sasaran: Terkendalinya kualitas lingkungan hidup.

c. Misi Ketiga, Meningkatkan daya tarik pariwisata, bertujuan: Mengembangkan industry pariwisata yang berdaya saing dan terintegrasi dengan wilayah sekitarnya, dengan sasaran: Meningkatnya peran pariwisata dalam perekonomian daerah.

d. Misi Keempat, Meningkatkan kualitas Sumber Daya Manusia, bertujuan: Meningkatkan kesejahteraan masyarakat, dengan sasaran: Meningkatnya kualitas pelayanan pendidikan; Meningkatnya pelayanan kualitas kesehatan; iii. Meningkatkan perekonomian masyarakat.

e. Misi kelima, Menyediakan Infrastruktur yang memadai, bertujuan: Mengoptimalkan dukungan infrastruktur terhadap pemenuhan pelayanan dasar dan pengembangan wilayah, dengan sasaran: Meningkatnya aksesbilitas transportasi darat; Meningkatnya kualitas pelayanan infrastruktur dasar.

f. Misi Keenam, Menciptakan Birokrasi Pemerintahan yang Baik, Bersih dan Melayani, bertujuan: Meningkatkan kapasitas dan kinerja birokrasi pemerintahan, dengan sasaran: Meningkatnya pelayanan prima kepada masyarakat; Meningkatnya kualitas perencanaan, pengendalian dan evaluasi kebijakan pembangunan dan pengelola-an keuangan yang transparan dan akunTabel.

g. Misi Ketujuh, Mempersiapkan kabupaten yang berdaya saing menghadapi Masyarakat Ekonomi ASEAN (MEA) dan menuju Indonesia sebagai poros maritim dunia, bertujuan:

1) Meningkatkan posisi daya saing daerah, dengan sasaran: Meningkatnya kemampuan ekonomi daerah; Meningkatnya iklim investasi daerah; Meningkatnya nilai eksport daerah; Meningkatnya kualitas tenaga kerja yang berdaya saing.

2) Meningkatkan pemerataan hasil pembangunan, dengan sasaran: Meningkatnya taraf hidup ekonomi dan kesejahteraan sosial masyarakat; Meningkatnya kesetaraan gender dalam pembangunan.

\section{Hasil Penelitian}

1. Kontribusi Kategori Lapangan Usaha terhadap PDRB ADHK Kabupaten Minahasa Utara Tahun 2013-2017.

Kabupaten Minahasa Utara merupakan salah satu wilayah potensial di Provinsi Sulawesi Utara. Kekayaan alam yang dimiliki berupa hasil bumi dan panorana alam yang indah menjadikan kabupaten ini sebagai destinasi pilihan untuk kegiatan wisata maupun aktifitas ekonomi. Melihat peluang yang ada, pemerintah Provinsi maupun daerah harus mempercepat pembangunan daerah dengan mengelola dan memanfaatkan potensi serta kekayaan yang dimiliki. Perhatian selanjutnya ditujukan untuk mengetahui komposisi ekonomi lewat peranan aktivitas kategori atau sektor lapangan usaha yang ada di Kabupaten Minahasa Utara. Tabel 5 menunjukkan peranan masing-masing lapangan usaha dalam kontribusinya terhadap pertumbuhan ekonomi lewat pembentukan Produk Domestik Regional Bruto Kabupaten Minahasa Utara.

Tabel 5 menunjukkan tentang persentase kontribusi kategori lapangan usaha terhadap PDRB Kabupaten Minahasa Utara periode 2013-2017 mengalami fluktuasi dan selama lima tahun terakhir kategori pertanian, kehutanan dan perikanan memiliki persentase kontribusi yang paling besar dibandingkan dengan kategori lapangan usaha yang lainnya. Pada tahun 2017 dapat dilihat persentase kontribusi kategori pertanian, kehutanan dan perikanan tetap menjadi kategori dengan Persentase kontribusi terbesar dengan nilai 26,54\%, kemudian diikuti oleh kategori lapangan usaha konstruksi yang menduduki peringkat kedua sebesar 15,22\%, diikuti dengan kategori lapangan usaha industri pengolahan sebesar $13,35 \%$ pada peringkat ketiga dan kategori pertambangan dan penggalian sebesar $10,90 \%$ pada peringkat keempat.

\begin{tabular}{|c|c|c|c|c|c|}
\hline KATEGORI & 2013 & 2014 & 2015 & 2016 & 2017 \\
\hline Pertanian, Kehutanan, dan Penikanan & 29.45 & 28.99 & 27.88 & 27.06 & 26.54 \\
\hline Pertambangandan Penggalian & 10.30 & 10.30 & 10.59 & 10.79 & 10.90 \\
\hline Industri Pengolahan & 14.04 & 13.72 & 13.51 & 12.75 & 13.35 \\
\hline Pengadaan Listrk danGas & 0.11 & 0.12 & 0.12 & 0.13 & 0.13 \\
\hline Pengadaan Air, Pengelolaan Sampah, Limbahdan Daur Clang & 0.09 & 0.08 & 0.08 & 0.08 & 0.07 \\
\hline Konstruksi & 13.38 & 13.73 & 14.35 & 15.02 & 15.22 \\
\hline Perdagangan Besar danEceran; Reparasi Mobil dan Sepeda Motor & 9.26 & 9.49 & 9.53 & 9.58 & 9.37 \\
\hline Transportasi dan Pergudangan & 4.13 & 4.19 & 4.24 & 4.30 & 4.37 \\
\hline PenyediaanAkomodas dan MakanMinum & 1.00 & 1.02 & 1.04 & 1.09 & 1.09 \\
\hline Informasi dan Konmikasi & 1.95 & 2.00 & 2.05 & 2.12 & 2.08 \\
\hline Jasa KeuangandanAsuransi & 0.81 & 0.78 & 0.76 & 0.87 & 0.94 \\
\hline Real Estate & 5.45 & 5.59 & 5.74 & 5.91 & 6.05 \\
\hline Jasa Perusahaan & 0.02 & 0.02 & 0.02 & 0.02 & 0.02 \\
\hline Administras Pemerintahan, Pertahanan dan Jaminan Sosial Wajib & 3.90 & 3.98 & 4.04 & 4.06 & 3.63 \\
\hline Jasa Pendidikan & 2.84 & 2.77 & 2.82 & 2.88 & 2.89 \\
\hline Jasa Kesehatan dan Kegiatan Sosial & 2.65 & 2.60 & 2.63 & 2.69 & 2.72 \\
\hline Jasa lainnya & 0.63 & 0.61 & 0.62 & 0.63 & 0.63 \\
\hline TOTAL & 100 & 100 & 100 & 100 & 100 \\
\hline
\end{tabular}


2. Kategori Basis di Kabupaten Minahasa Utara Mengenal lebih mendalam potensi yang dimiliki serta peluang pengembangannya adalah suatu yang sangat mendasar dalam proses perencanaan pembangunan khususnya untuk perencanaan dalam konteks lokal, sebab tanpa pengetahuan tentang hal tersebut perencanaan pembangunan daerah berjalan tanpa ada prioritas. Implikasinya kemudian adalah pembangunan daerah berjalan secara stagnan, oleh karena itu penting untuk menentukan sektor mana yang menjadi prioritas dan berpeluang untuk dikembangkan sebagai basis ekonomi.

Analisis Location Quotient (LQ) digunakan untuk mengetahui sektor-sektor ekonomi dalam PDRB yang dapat digolongkan ke dalam sektor basis dan non basis. Location Quotient merupakan suatu perbandingan tentang besarnya peranan suatu sektor di Kabupaten Minahasa Utara terhadap besarnya peranan sektor yang sama di tingkat Provinsi (Sulawesi Utara). Nilai LQ > 1 menjelaskan bahwa peranan suatu sektor di Kabupaten Minahasa Utara lebih dominan dibandingkan sektor yang ada di tingkat Provinsi Sulawesi Utara dan sebagai petunjuk bahwa kabupaten surplus terhadap sektor atau kategori tersebut. Nilai LQ $<1$ menunjukkan bahwa peranan sektor tersebut lebih kecil dibandingkan tingkat Provinsi.

Nilai LQ dapat dikatakan sebagai petunjuk untuk dijadikan dasar dalam menentukan sektor yang potensial untuk dikembangkan. Sektor yang potensial tersebut tidak saja dapat memenuhi kebutuhan didalam daerah, akan tetapi dapat juga memenuhi kebutuhan di daerah lain atau surplus. Logika dasar LQ adalah teori basis ekonomi yang intinya adalah karena industri basis menghasilkan barang-barang dan jasa untuk pasar di daerah maupun di luar daerah yang bersangkutan, maka penjualan keluar daerah akan menghasilkan pendapatan bagi daerah tersebut. Adanya pendapatan yang didapatkan dari luar daerah ini akan menyebabkan terjadinya kenaikan konsumsi dan investasi di daerah tersebut. Aktifitas ini kemudian akan menaikan pendapatan dan menciptakan kesempatan untuk terbukanya lapangan kerja baru. Peningkatan pendapatan tersebut juga akan menaikan permintaan akan industri basis, tetapi juga menaikan permintaan terhadap industri non basis (lokal). Analisis Location Quotient (LQ) Kabupaten Minahasa Utara dari kurun waktu tahun 2013-2017 disajikan pada Tabel 6 .

\begin{tabular}{|c|c|c|c|c|c|c|c|}
\hline No & KATEGORI & 2013 & 2014 & 2015 & 2016 & 2017 & Rata-rata \\
\hline 1 & Pertanian, Kehutanan, dan Perikanan & $\frac{2013}{1.34}$ & $\frac{2014}{1.35}$ & $\frac{2015}{1.34}$ & $\frac{2010}{1.34}$ & $\frac{2017}{1.33}$ & 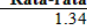 \\
\hline 2 & Pertambangan dan Penggalian & 2.13 & 2.12 & 2.13 & 2.21 & 2.17 & 2.15 \\
\hline 3 & Industri Pengolahan & 1.27 & 1.28 & 1.30 & 1.29 & 1.32 & 1.29 \\
\hline 4 & Pengadaan Listrik dan Gas & 1.15 & 1.10 & 1.07 & 1.04 & 1.04 & 1.08 \\
\hline 5 & $\begin{array}{l}\text { Pengadaan Air, Pengelolaan Sampah, } \\
\text { Limbah dan Daur Ulang }\end{array}$ & 0.59 & 0.58 & 0.58 & 0.58 & 0.58 & 0.58 \\
\hline 6 & Konstruksi & 1.05 & 1.08 & 1.10 & 1.14 & 1.14 & 1.10 \\
\hline 7 & $\begin{array}{l}\text { Perdagangan Besar dan Eceran; } \\
\text { Reparasi Mobil dan Sepeda Motor }\end{array}$ & 0.74 & 0.74 & 0.74 & 0.75 & 0.74 & 0.74 \\
\hline 8 & Transportasi dan Pergudangan & 0.51 & 0.50 & 0.50 & 0.49 & 0.50 & 0.50 \\
\hline 9 & Penyediaan Akomodasi dan Makan & 0.48 & 0.48 & 0.47 & 0.47 & 0.47 & 0.47 \\
\hline 10 & Informasi dan Komunikasi & & 0.45 & & & & \\
\hline 11 & Jasa Keuangan dan Asuransi & 0.21 & 0.21 & 0.21 & 0.22 & 0.24 & 0.22 \\
\hline 12 & Real Estate & 1.53 & 1.53 & 1.55 & 1.58 & 1.61 & 1.56 \\
\hline 13 & Jasa Perusahaan & 0.20 & 0.20 & 0.20 & 0.20 & 0.20 & 0.20 \\
\hline 14 & $\begin{array}{l}\text { Administrasi Pemerintahan, Pertahanan } \\
\text { dan Jaminan Sosial Wajib }\end{array}$ & 0.57 & 0.57 & 0.56 & 0.57 & 0.52 & 0.56 \\
\hline 15 & Jasa Pendidikan & 1.12 & 1.12 & 1.12 & 1.15 & 1.16 & 1.13 \\
\hline 16 & Jasa Kesehatan dan Kegiatan Sosial & 0.71 & 0.70 & 0.69 & 0.70 & 0.69 & 0.70 \\
\hline 17 & Jasa lainnya & 0.40 & 0.39 & 0.39 & 0.39 & 0.38 & 0.39 \\
\hline
\end{tabular}

Berdasarkan hasil analisis LQ pada tahun 2013-2017 kategori lapangan usaha yang memiliki nilai LQ lebih dari 1 (LQ > 1) adalah sebagai berikut:

a. Kategori Pertanian, Kehutanan dan Perikanan

Kategori lapangan usaha pertanian, kehutanan dan perikanan merupakan kategori dengan kontribusi terbesar terhadap pembentukan PDRB Kabupaten Minahasa Utara (Tabel 5). Kategori ini konsisten memberikan kontribusi terbesar pada PDRB Kabupaten Minahasa Utara sejak tahun 2013 sebesar $29,45 \%$, tahun 2014 sebesar 28,99\%, tahun 2015 sebesar 27,88\%, tahun 2016 sebesar $27,06 \%$ dan tahun 2017 sebesar 26,54\%. Kontribusi terbesar yang ditunjukan oleh kategori pertanian, kehutanan dan perikanan terus menurun tiap tahunnya, kontribusi yang tinggi tersebut juga tidak berpengaruh signifikan terhadap jumlah LQ yang dimiliki kategori ini yaitu rata-rata sebesar 1.34 atau bukan yang tertinggi di Kabupaten Minahasa Utara. Nilai LQ sebesar 1,34 yang diperoleh kategori pertanian kehutanan dan perikanan menunjukkan bahwa kategori ini dapat memenuhi kegiatan konsumsi di Kabupaten Minahasa Utara tetapi juga mampu untuk di ekspor atau dialokasikan ke daerah lain. Nilai LQ>1 yang diperoleh kategori pertanian, kehutanan dan perikanan menunjukkan bahwa kategori ini merupakan kategori basis atau kategori ekonomi yang unggul di kabupaten Minahasa Utara. Hasil perolehan ini sejalan dengan penetapan visi oleh Pemerintah Daerah Kabupaten Minahasa Utara yang menetapkan Kabupaten Minahasa Utara sebagai Kabupaten Agribisnis yang diharapkan akan memacu 
transformasi aktivitas ekonomi yang lainnya. Komoditas tanaman pangan di Kabupaten Minahasa Utara didominasi oleh tanaman padi khususnya padi sawah dan tanaman jagung. Bantuan Pemerintah Kabupaten Minahasa Utara lewat pemberian bibit dan program cetak sawah memacu kenaikan produksi kedua tanaman pangan ini. Produksi padi di Kabupaten Minahasa Utara pada tahun 2017 sebanyak 93.070 ton atau meningkat dari tahun 2016 yang tercatat hanya 50.625 ton. Pada tahun 2017 produksi jagung mencapai 335.739 ton atau naiuk signifikan dari tahun 2016 yang hanya 96.146 ton. Potensi tanaman hortikultura di Kabupaten Minahasa Utara khususnya tanaman sayuran yang paling banyak tumbuh ialah tanaman cabe rawit, dengan luas panen sebesar 318 hektar dan produksi mencapai 691,1 ton pada tahun 2016. Potensi tanaman perkebunan yang banyak di temukan di Minahasa Utara ialah tanaman perkebunan kelapa. Luas areal perkebunan kelapa di Minahasa Utara sebesar 42.703 hektar dengan produksi mencapai 43.188 ton. Aktivitas kategori pertanian kehutanan dan perikanan di kabupaten Minahasa Utara diwakili juga oleh aktivitas subkategori kehutanan dengan hasil hutan berupa kayu bulat sebesar $2.646 \mathrm{~m}^{3}$ pada tahun 2016 dan aktivitas subsektor perikanan dengan total hasil produksi perikanan laut sebesar $17.432,80$ ton pada tahun 2016.

b. Pertambangan dan Penggalian

Kategori pertambangan dan penggalian merupakan kategori dengan nilai LQ tertinggi di Kabupaten Minahasa Utara yaitu rata-rata sebesar 2,15. Kegiatan ini meliputi seluruh aktifitas penggalian, pengeboran, penyaringan dan pengambilan segala macam barang tambang, mineral dan barang galian yang tersedia di alam. Aktivitas kategori lapangan usaha pertambangan dan penggalian di Minahasa Utara menyumbangkan Persentase sebesar $10,30 \%$ pada tahun 2013, 20,30\% pada tahun $2014,10,59 \%$ pada tahun $2015,10,79 \%$ pada tahun 2016 dan $10,90 \%$ kontribusi terhadap PDRB Kabupaten Minahasa Utara tahun 2017. Angka kontribusi kategori pertambangan dan penggalian di Minahasa Utara menunjukkan kenaikan setiap tahun sejak tahun 2014 sampai tahun 2017. Potensi kategori pertambangan dan penggalian di Minahasa Utara meliputi mineral logam dan non logam (batuan dan energi). Emas dan perak merupakan mineral logam yang sangat berpotensi dan telah dilakukan eksploitasi di kecamatan likupang timur, dimembe dan talawaan. Selain emas dan perak logam lain yang memiliki potensi di Minahasa Utara adalah logam besi (Kecamatan Likupang Timur), pasir besi (Kecamatan Wori dan Kema), dan mangan (Kecamatan Likupang Barat). Sedangkan mineral non logam yang berpotensi di Kabupaten Minahasa utara adalah batu andesit, lapis, sirtu, krikil, pasir, dan teras. PT Maeres Soputan Mining merupakan salah satu perusahaan pertambangan besar di Kabupaten Minahasa Utara, aktivitas perusahaan ini ialah eksploitasi tambang emas yang berada di Kecamatan Likupang Timur. Perusahaan ini merupakan perusahaan pertambangan dengan pembayaran pajak terbesar di Provinsi Sulawesi Utara.

c. Industri Pengolahan

Kategori selanjutnya yang memiliki nilai LQ diatas 1 adalah kategori lapangan usaha industri pengolahan. Kategori ini mendapatkan nilai LQ rata-rata sebesar 1,29. Upaya untuk mewujudkan kawasan industri skala besar diarahkan ke wilayah Kecamatan Kauditan dan Kecamatan Kema untuk mendukung Kawasan Ekonomi Khusus (KEK) yang ada di Kota Bitung, dan di Kecamatan Likupang Barat, Kecamatan Likupang Selatan, dan Kecamatan Likupang Timur. Aktivitas kegiatan industri pengolahan di Kabupaten Minahasa Utara didominasi oleh industri kimia, bangunan, serta industri makanan dan minuman. Kontribusi kategori industri pengolahan mengalami penurunan nilai kontribusi terhadap PDRB Kabupaten Minahasa Utara sejak tahun 2013 sebesar $14,04 \%$, turun menjadi $13,72 \%$ pada tahun 2014, 13,51\% pada tahun 2015 dan angka kontribusi terendah pada tahun 2016 sebesar $12,75 \%$. Pada tahun 2017 kategori ini menunjukkan adanya kenaikan kontribusi dari sektor sebelumnya menjadi $13,35 \%$. Pada tahun 2017, sebesar 58\% industri di Minahasa Utara merupakan industri kimia dan bahan bangunan, $25 \%$ merupakan industri pangan, $12 \%$ merupakan industri logam dan elektronik, 3\% merupakan industri sandang dan kulit serta $2 \%$ merupakan industri kerajinan umum. Industri logam dan elektronika menyerap jumlah tenaga kerja terbanyak yaitu sebesar 1.296 orang pekerja diikuti industri pangan dengan serapan pekerja sebesar 1.913 orang dan industri kimia dan bangunan sebesar 1.296 orang pekerja. Kegiatan industri merupakan salah satu kategori lapangan usaha yang diunggulkan di Kabupaten Minahasa Utara lewat visi dan misi yang ditetapkan oleh Pemerintah Kabupaten 
Minahasa Utara serta fokus pemerintah untuk membuat kategori industri menjadi penopang perekonomian daerah. Kategori lapangan usaha industri pengolahan merupakan kategori yang sangat potensial untuk dikembangkan, hal ini dikarenakan Kabupaten Minahasa Utara terletak diantara dua kota yaitu Kota Manado dan Kota Bitung.

d. Pengadaan Listrik dan Gas

Kategori pengadaan listrik dan gas mendapatkan nilai LQ sebesar 1,08 dengan kontribusi terhadap PDRB Kabupaten Minahasa Utara sebesar $0,11 \%$ pada tahun $2013,0,12 \%$ pada tahun 2014, 0,12 pada tahun 2015, naik menjadi 0,13\% pada tahun 2016 dan nilai yang sama sebesar $0,13 \%$ pada tahun 2017. kontribusi ini terbilang kecil atau ketiga terkecil kontribusinya terhadap PDRB Kabupaten Minahasa Utara. Kategori pengadaan listrik dan gas mencakup kegiatan ekonomi atau lapangan usaha pengadaan tenaga listrik, gas alam dan sejenisnya melalui jaringan saluran atau pipa infrastruktur permanen. Kegiatan atau aktivitas kategori ini termasuk kegiatan distribusi listrik, gas dan sejenisnya dalam lokasi pabrik atau bangunan tempat tinggal. Perusahaan Listrik Negara menjadi penyedia penerangan utama di Minahasa Utara. Hampir seluruh wilayah di Minahasa Utara menggunakan listrik PLN sebagai penerangan utama yaitu mencapai $98,73 \%$, sedangkan sisanya 1,27 menggunakan penerangan listrik non PLN dan non listrik. Pada tahun 2017 jumlah pelanggan listrik PLN meningkat dibandingkan tahun 2016. Pelanggan PLN meningkat menjadi 44.924 pelanggan dari sebelumnya sebesar 42.312 pelanggan. Daya terpasang mengalami peningkatan yang tinggi bersamaan dengan listrik terjual. Pada tahun 2017 daya terpasang menjadi 97.776 mega watt dari tahun sebelumnya sebesar 88.563 mega watt.

e. Konstruksi

Kategori konstruksi merupakan salah satu kategori basis di Kabupaten Minahasa Utara. Kategori ini mendapatkan nilai LQ rata-rata sebesar 1,10 dengan kontribusi terhadap PDRB Kabupaten Minahasa Utara sebesar 13,38\% pada tahun 2013, 13,73\% pada tahun 2014, $14,35 \%$ pada tahun $2015,15,02 \%$ pada tahun 2016 , dan $15,22 \%$ pada tahun 2017. Kategori ini menunjukkan kenaikan kontribusi setiap tahun sejak tahun 2013 sampai tahun 2017, kategori konstruksi juga merupakan kontribusi terbesar kedua setelah kategori pertanian, kehutanan, dan perikanan. Kategori ini mencakup kegiatan ekonomi atau lapangan usaha di bidang konstruksi, yaitu kegiatan konstruksi umum dan konstruksi khusus pekerjaan bangunan gedung dan bangunan sipil. Aktivitas kategori konstruksi mencakup pekerjaan baru, perbaikan, penambahan, dan perubahan pendirian bangunan atau struktur bangunan. Aktifitas pembangunan fisik berupa fasilitas umum di Kabupaten Minahasa Utara terus meningkat, kegiatan ini bisa dilihat dari aktivitas pembangunan hotel, rumah sakit, gudang, dan bangunan untuk kegiatan wisata di Kabupaten Minahasa Utara.

f. Real estate

Kategori real estate mendapatkan nilai LQ rata-rata sebesar $1,56 \%$. Kategori ini memberikan kontribusi terhadap PDRB Minahasa Utara sebesar 5,45\% pada tahun 2013, 5,59\% pada tahun $2014,5,74 \%$ pada tahun $2015,5,91 \%$ pada tahun 2016, dan 6,05\% pada tahun 2017. Kegiatan kategori ini meliputi kegiatan persewaan dan jual beli barang-barang tidak bergerak (bangunan dan tanah) termasuk agen atau broker yang menangani persewaan, pembelian, dan penaksiran nilai tanah/bangunan atas balas jasa atau kontrak.

g. Jasa Pendidikan

Kategori jasa pendidikan merupakan salah satu kategori lapangan usaha yang mendapatkan nilai LQ lebih dari 1 yaitu rata-rata sebesar 1,13. Kategori ini memberikan kontribusi berturutturut sebesar 2,84\% pada tahun 2013, 2,77\% pada tahun 2014, 2,82\% pada tahun 2015, $2,88 \%$ pada tahun 2016 , dan $2,89 \%$ pada tahun 2017. Aktivitas dalam kategori ini mencakup kegiatan paa berbagai tingkatan maupun berbagai pekerjaan, baik secara lisan atau tertilis. Kegiatan atau aktivitas kategori jasa pendidikan mencakup semua lembaga pendidikan swasta seperti play group sampai dengan perguruan tinggi, termasuk juga kegiatan kursus atau pelatihan. Kabupaten Minahasa Utara memiliki beberapa sekolah dan universitas swasta unggulan diantaranya Manado Independen School, SMA Klabat, dan Universitas Klabat yang menjadi pilihan untuk masyarakat Minahasa Utara maupun masyarakat di luar Kabupaten Minahasa Utara untuk bersekolah.

Perumusan visi dan misi Pemerintah Kabupaten Minahasa Utara salah satunya adalah penetapan Kabupaten Minahasa Utara sebagai Kabupaten pariwisata. Pesona alam Minahasa Utara yang indah menjadi modal utama yang penting untuk mengembangkan sektor 
pariwisata di Minahasa Utara. Keindahan sumber daya alam yang terkenal antara lain pesona gunung klabat, pantai pasir putih pulau lihaga, pantai paal, pantai pulisan, kaki dian, wisata budaya dan sejarah waruga dan lokasi wisata lainnya. Pengembangan sektor pariwisata di Kabupaten Minahasa utara dapat dilihat dari lewat aktifitas kategori penyediaan akomodasi dan makan minum. Kategori penyediaan akomodasi dan makan minum belum menunjukkan peranan yang baik dalam kontribusinya terhadap Produk Domestik Regional Bruto Kabupaten Minahasa Utara. Hasil perhitungan kontribusi pada Tabel 5 menunjukkan hasil yang terbilang kecil atau hanya sebesar $1,09 \%$ kontribusi terhadap PDRB Kabupaten Minahasa Utara. Hasil perhitungan Location Quotient pada Tabel 6 kategori penyediaan akomodasi dan makan minum mendapatkan rata-rata nilai LQ sebesar $0,47 \%$ artinya bahwa kategori ini tidak unggul dibandingkan dengan kategori yang sama pada tingkat Provinsi Sulawesi Utara. Sumber daya alam yang melimpah lewat objek wisata yang menarik belum diimbangi dengan pengelolaan yang optimal oleh pihak terkait dalam hal ini Pemerintah Daerah Kabupaten Minahasa Utara. Produk wisata berupa akomodasi, tempat makan, dan fasilitas penunjang lainnya belum dikelola dengan baik sehingga wisatawan baik mancanegara maupun domestik hanya datang menikmati keindahan alam yang ada di kabupaten Minahasa Utara kemudian melakukan aktivitas yang menguntungkan dari segi ekonomi seperti penyewaan hotel dan makan minum di Ibu Kota Provinsi Sulawesi Utara yaitu Kota Manado yang bisa ditempuh selama dua jam perjalanan dari lokasi wisata di Kabupaten Minahasa Utara.

\section{Hasil analisis shift share}

Analisis shift share mengasumsikan bahwa perubahan pendapatan (PDRB) suatu wilayah dpat dibagi dalam tiga komponen yaitu komponen pengaruh pertumbuhan provinsi atau Regional Share (Nij), komponen bauran industri atau Proportional Shift (Mij) dan komponen pertumbuhan pangsa wilayah atau Differential Shift (Cij). Hasil Analisis Shift Share Nilai PDRB Kabupaten Minahasa Utara Tahun 2013-2017 (Rp. Juta) adalah sebagai berikut :
Tabel 7. Hasil Analisis Shift Share Kategori Lapangan Usaha PDRB Kabupaten Minahasa Utara Periode 2013-2017 (Juta Rupiah)

\begin{tabular}{|c|c|c|c|c|c|}
\hline No & KATEGORI & $\mathrm{Nij}$ & Mij & Cij & Dij \\
\hline 1 & Pertanian, Kethutanan, dan Perikanan & $12,663,752.95$ & $-5,494,671.22$ & $1,536,817.00$ & $8,705,898.66$ \\
\hline 2 & Pertambargan dan Penggalian & $4,814,823.87$ & $755,178.73$ & $1,031,573.00$ & $6,001,575.34$ \\
\hline 3 & Industri Pengolahan & $6,106,021.15$ & $-2,359,829.91$ & $1,891,589.00$ & $5,637,780.11$ \\
\hline 4 & Pengodann Listrik dan Gas & $56,388.75$ & $56,367.62$ & $-17,067.60$ & $95,688.74$ \\
\hline 5 & Pengadarn Air, Pengelolan Sampeh, Limbah dan Daur Ulang & $36,106.78$ & $-22,262.13$ & 3,50581 & $17,350.46$ \\
\hline 6 & Kontruksi & $6,545,208.90$ & $1,349,293.60$ & $3,165,750,00$ & $11,060,252.67$ \\
\hline 7 & Perdagangan Bear dan Eceran; Reparasi Mobil dan Sepeda Motor & $4,292,691.69$ & $348,884.86$ & 438,06030 & $5,079,636.85$ \\
\hline 8 & Trangportas dan Pergudangan & $1,932,289.74$ & $600,047.80$ & 115,03130 & $2,647,368.87$ \\
\hline 9 & Peayediann Akomodads ian Malkan Mirum & $477,216.90$ & $253,113.06$ & $-8,849.03$ & $721,480.93$ \\
\hline 10 & Informasi dan Komurikasi & $929,126.96$ & $344,490.59$ & $34,334.10$ & $1,307,951.65$ \\
\hline 11 & Jase Keuargan dan $A$ & $380,433.01$ & $116,643.64$ & 212,31630 & $709,392.92$ \\
\hline 12 & Real Estate & $2,619,505.02$ & $621,984.05$ & $890,755.10$ & $4,132,264.14$ \\
\hline 13 & Jase Peruschan & $7,359.92$ & $2,140.20$ & 863.76 & $10,363.88$ \\
\hline 14 & Administras Pemerintahan, Perthanan dan Jaminan Sosial Wajit & $1,778,560.15$ & $224,290.31$ & $-507,869.00$ & $1,494,981.94$ \\
\hline 15 & Jase Pendidikan & $1,290,992.65$ & $-94,993.10$ & $370,652.80$ & $1,566,652.36$ \\
\hline & Jas Kesehatan dan Kegiatan Sosial & $1,209,118.90$ & 231,919.15 & $7,210.64$ & $1,513,248.69$ \\
\hline \multirow[t]{2}{*}{17} & Jas lainnya & 283,35236 & $48,161.38$ & $-1,881.04$ & $329,632.71$ \\
\hline & TOTAL & $45,422,949.72$ & $-3,019,241.37$ & $9,227,812.44$ & $51,631,520.91$ \\
\hline
\end{tabular}

Tabel 7 menunjukkan hasil perhitungan perkembangan Regional Share (Nij) dan Proportional Shift (Mij) dan Differential Shift (Cij) (Kabupaten Minahasa Utara tahun 2013-2017 maka dapat dilihat peranan sektor atau kategori basis yang sudah dihitung sebagai berikut :

a. Pertanian, kehutanan dan perikanan.

Perkembangan PDRB regional Kabupaten Minahasa Utara (regional share) untuk kategori pertanian, kehutanan dan perikanan membawa dampak yang positif terhadap PDRB provinsi Sulawesi Utara, hal ini ditandai dengan meningkatnya PDRB Kabupaten Minahasa Utara sebesar Rp.12,663,752.95 atau 17,21\% dari PDRB Kategori pertanian, kehutanan dan perikanan Provinsi Sulawesi Utara. Hasil ini juga menunjukkan bahwa perekonomian regional Minahasa Utara khususnya kategori pertanian, kehutanan dan perikanan tumbuh lebih cepat dibandingkan pertumbuhan kategori pertanian, kehutanan dan perikanan provinsi Sulawesi Utara. Kategori pertanian, kehutanan dan perikanan merupakan komponen dengan angka regional share yang paling tinggi diantara seluruh kategori lapangan usaha yang ada di kabupaten Minahasa Utara.

Pergeseran proposional (Propotional Shift) kategori pertanian, kehutanan dan perikanan menunjukkan hasil Propotional Shift yang negatif yaitu sebesar -5,494,671.22. penilaian secara kategori menunjukkan bahwa kategori pertanian, kehutanan dan perikanan lambat kemajuan atau pertumbuhannya dibandingkan dengan kategori yang sama pada level perekonomian provinsi Sulawesi utara.

Pergeseran diferensial (Differential Shift) kategori pertanian, kehutanan dan perikanan untuk perekonomian regional Kabupaten Minahasa Utara memiliki keunggulan kompetitif atau cepat terhadap perekonomian Sulawesi Utara. Hal ini terlihat pada nilai Differential Shift yang positif yaitu sebesar 
Rp.1,536,817.00. kategori ini memiliki daya saing yang kuat atau memiliki keunggulan kompetitif yang tinggi dibandingkan dengan kategori yang sama pada tingkat provinsi Sulawesi Utara.

b. Pertambangan dan penggalian

Kategori pertambangan dan penggalian kabupaten Minahasa Utara berdasarkan analisis shift share tahun 2013-2017 memiliki komponen pertumbuhan regional share yang positif yaitu sebesar Rp.4,814,823.87 atau $27,66 \%$ terhadap kontribusi PDRB provinsi Sulawesi Utara.

Pergeseran proposional (Propotional Shift) kategori pertambangan dan penggalian menunjukkan hasil Propotional Shift yang positif yaitu sebesar Rp.755,178.73. penilaian secara kategori menunjukkan bahwa kategori pertambangan dan penggalian cepat kemajuan atau pertumbuhannya dibandingkan dengan kategori yang sama pada level perekonomian provinsi Sulawesi utara.

Pergeseran diferensial (Differential Shift) kategori pertambangan dan penggalian untuk perekonomian regional Kabupaten Minahasa Utara memiliki keunggulan kompetitif yang atau cepat terhadap perekonomian Sulawesi Utara. Hal ini terlihat pada nilai Differential Shift yang positif yaitu sebesar Rp.1,031,573.00. kategori ini memiliki daya saing yang kuat atau memiliki keunggulan kompetitif yang tinggi dibandingkan dengan kategori yang sama pada tingkat provinsi Sulawesi Utara.

c. Industri pengolahan

Kategori industri pengolahan Minahasa Utara berdasarkan regional share tahun 2013-2017 menunjukkan hasil yang positif. Pengaruh komponen regional share kategori Industri pengolahan sebesar Rp.6,106,021.15 memberikan dampak yang positif terhadap kontribusi pembentukan PDRB kategori industri pengolahan provinsi Sulawesi Utara yaitu sebesar $16,59 \%$.

Pergeseran proposional (Propotional
Shift) kategori industri pengolahan
menunjukkan hasil Propotional Shift negatif
yaitu sebesar $-2,359,829.91$. penilaian secara
kategori menunjukkan bahwa kategori
industri pengolahan lambat kemajuan atau
pertumbuhannya dibandingkan dengan
kategori yang sama pada level perekonomian
provinsi Sulawesi utara.

Pergeseran diferensial (Differential Shift) kategori industri pengolahan untuk perekonomian regional Kabupaten Minahasa Utara memiliki keunggulan kompetitif yang atau cepat terhadap perekonomian Sulawesi Utara. Hal ini terlihat pada nilai Differential Shift yang positif yaitu sebesar Rp.1,891,589.00, kategori ini memiliki daya saing yang kuat atau memiliki keunggulan kompetitif yang tinggi dibandingkan dengan kategori yang sama pada tingkat provinsi Sulawesi Utara.

d. Pengadaan listrik dan gas

Perkembangan PDRB regional Kabupaten Minahasa Utara (regional share) untuk kategori pengadaan listrik dan gas membawa dampak yang positif terhadap PDRB kategori yang sama pada level provinsi Sulawesi Utara, hal ini ditandai dengan nilai PDRB kategori pengadaan listrik dan gas sebesar Rp.56,388.75 atau kontribusi sebesar $13,81 \%$ untuk kategori yang sama di level provinsi Sulawesi Utara.

Pergeseran proposional (Propotional Shift) kategori pengadaan listrik dan gas menunjukkan hasil Propotional Shift yang positif yaitu sebesar 56,367.62. penilaian secara kategori menunjukkan bahwa kategori pengadaan listrik dan gas cepat kemajuan atau pertumbuhannya dibandingkan dengan kategori yang sama pada level perekonomian provinsi Sulawesi utara.

Pergeseran diferensial (Differential Shift) kategori pengadaan listrik dan gas untuk perekonomian regional Kabupaten Minahasa Utara memiliki nilai yang negatif yaitu sebesar 17,067.60, kategori ini tidak memiliki daya saing yang kuat atau keunggulan kompetitif yang rendah dibandingkan dengan kategori pengadaan listrik dan gas pada tingkat provinsi Sulawesi Utara.

e. Konstruksi

Kategori konstruksi Minahasa Utara berdasarkan regional share tahun 2013 - 2017 menunjukkan hasil yang positif. Pengaruh komponen regional share kategori konstruksi sebesar Rp.6,545,208.90 memberikan dampak yang positif terhadap kontribusi pembentukan PDRB kategori yang sama pada tingkat provinsi Sulawesi Utara yaitu sebesar $14,22 \%$.

Pergeseran proposional (Propotional Shift) kategori konstruksi menunjukkan hasil Propotional Shift yang positif yaitu sebesar 1,349,293.60. penilaian secara kategori menunjukkan bahwa kategori konstruksi cepat kemajuan atau pertumbuhannya dibandingkan dengan kategori yang sama pada level perekonomian provinsi Sulawesi utara.

Pergeseran diferensial (Differential Shift) kategori konstruksi untuk perekonomian regional Kabupaten Minahasa Utara memiliki keunggulan kompetitif terhadap perekonomian Sulawesi Utara. 
Hal ini terlihat pada nilai Differential Shift yang positif yaitu sebesar 3,165,750.00. kategori ini memiliki daya saing yang kuat atau memiliki keunggulan kompetitif yang tinggi dibandingkan dengan kategori yang sama pada tingkat provinsi Sulawesi Utara.

f. Real Estate

Kategori real estate Minahasa Utara berdasarkan regional share tahun 2013 - 2017 menunjukkan hasil yang positif. Pengaruh komponen regional share kategori real estate sebesar Rp.2,619,505.02 memberikan dampak yang positif terhadap kontribusi pembentukan PDRB kategori real estate pada tingkat provinsi Sulawesi Utara yaitu sebesar $20,09 \%$.

Pergeseran proposional (Propotional Shift) kategori real estate menunjukkan hasil Propotional Shift yang positif yaitu sebesar 621,984.05. penilaian secara kategori menunjukkan bahwa kategori real estate cepat kemajuan atau pertumbuhannya dibandingkan dengan kategori yang sama pada level perekonomian provinsi Sulawesi utara.

Pergeseran diferensial (Differential Shift) kategori real estate untuk perekonomian regional Kabupaten Minahasa Utara memiliki keunggulan kompetitif atau cepat terhadap perekonomian Sulawesi Utara. Hal ini terlihat pada nilai Differential Shift yang positif yaitu sebesar $890,775.10$. kategori ini memiliki daya saing yang kuat atau memiliki keunggulan kompetitif yang tinggi dibandingkan dengan kategori yang sama pada tingkat provinsi Sulawesi Utara.

g. Jasa pendidikan

Kategori jasa pendidikan Minahasa Utara berdasarkan regional share tahun 2013 - 2017 menunjukkan hasil yang positif. Pengaruh komponen regional share kategori jasa pendidikan sebesar Rp.1,290,992.65 memberikan dampak yang positif terhadap kontribusi pembentukan PDRB kategori yang sama pada tingkat provinsi Sulawesi Utara yaitu sebesar $14,56 \%$.

Pergeseran proposional (Propotional Shift) kategori Jasa pendidikan menunjukkan hasil Propotional Shift yang negatif yaitu sebesar -94,993.10. penilaian secara kategori menunjukkan bahwa kategori jasa pendidikan lambat kemajuan atau pertumbuhannya dibandingkan dengan kategori yang sama pada level perekonomian provinsi Sulawesi utara.

Pergeseran diferensial (Differential Shift) kategori jasa pendidikan untuk perekonomian regional Kabupaten Minahasa Utara memiliki keunggulan kompetitif atau cepat terhadap perekonomian Sulawesi Utara.
Hal ini terlihat pada nilai Differential Shift yang positif yaitu sebesar 370,652.80. kategori ini memiliki daya saing yang kuat atau memiliki keunggulan kompetitif yang tinggi dibandingkan dengan kategori yang sama pada tingkat provisi Sulawesi Utara.

Hasil keseluruhan analisis shift share (Dij) kategori-kategori lapangan usaha basis (kategori basis) di Kabupaten Minahasa Utara menunjukkan hasil yang positif terhadap nilai kategori yang sama pada tingkat Provinsi Sulawesi Utara. Peranan ini dapat dilihat pada hasil analisis shift share keseluruhan kabupaten Minahasa Utara tahun 2013-2017 pada Tabel 7 yang menunjukkan kontribusi positif kategorikategori lapangan usaha basis yaitu kategori pertanian, kehutanan, dan perikanan sebesar $8,705,898.66$, pertambangan dan penggalian sebesar 6,601,575.34, industri pengolahan sebesar 5,637,780.11, pengadaan listrik dan gas sebesar 95,688.74, konstruksi sebesar 11,060,252.67, dan kategori jasa pendidikan sebesar 1,566,652.36. Hasil ini menunjukkan bahwa kategori basis di Kabupaten Minahasa Utara memberikan kontribusi yang positif terhadap kategori yang sama pada perekonomian Sulawesi Utara.

\section{Analisis Incremental Capital Output Ratio (ICOR) Tahunan}

Salah satu faktor pendukung terciptanya pembangunan daerah yang berkualitas adalah tingginya tingkat efisiensi terhadap penggunaan investasi. Produktivitas investasi yang tinggi dapat mendorong terciptanya output yang bisa diperoleh suatu daerah. Incremental Capital Output Ratio (ICOR) merupakan suatu besaran yang menunjukkan besarnya tambahan kapital atau investasi yang diperlukan untuk menambah atau menaikan satu unit output.

Pengkajian ICOR sangat menarik dalam merefleksikan besarnya produktifitas investasi yang pada akhirnya ikut menentukan pertumbuhan ekonomi yang bisa dicapai. Tabel 8 merupakan hasil perhitungan ICOR tahunan di Kabupaten Minahasa Utara dengan menggunakan Lag 0 dan Lag 1. ICOR Lag 0 mencerminkan penggunaan investasi pada tahun analisi akan menghasilkan penambahan output pada tahun yang sama, sedangkan ICOR Lag 1 berarti investasi yang ditanamkan pada tahun analisis baru akan menghasilkan output pada tahun selanjutnya. 
Tabel 8. Hasil Analisis Incremental Capital Output Ratio Tahun 2013-2017 Kabupaten Minahasa Utara (Juta Rupiah)

\begin{tabular}{lrrrrr}
\multicolumn{7}{c}{ Tahun } & PMTDB & $\begin{array}{r}\text { PDRB } \\
\text { ADHK }\end{array}$ & $\begin{array}{r}\text { ICOR } \\
\text { Lag 0 }\end{array}$ & $\begin{array}{r}\text { ICOR } \\
\text { Lag 1 }\end{array}$ & $\begin{array}{r}\text { Rata-rata } \\
\text { Lag 0 }\end{array}$ \\
\hline 2013 & $2,941,385$ & $6,318,071$ & 7.21 & 6.21 & 8.03 \\
2014 & $3,221,618$ & $6,791,620$ & 6.80 & 6.75 & \\
2015 & $3,804,881$ & $7,269,174$ & 7.97 & 7.41 & \\
2016 & $4,333,193$ & $7,782,483$ & 8.44 & 8.55 & \\
2017 & $4,932,691$ & $8,289,247$ & 9.73 & - & \\
\hline
\end{tabular}

Sumber: Hasil Olahan ICOR, 2018

Tabel 8 menunjukkan hasil perhitungan Incremental Capital Output Ratio di Kabupaten Minahasa Utara pada periode 2013-2017 (Tabel 8) menunjukkan bahwa nilai ICOR berfluktuatif. Pada tahun 2013 nilai ICOR lag 0 Kabupaten Minahasa Utara diperoleh sebesar 7,21, artinya untuk memperoleh penambahan output PDRB sebesar 1 unit diperlukan investasi sebesar 7,21 unit. Pada tahun 2014 nilai ICOR lag 0 Minahasa Utara adalah sebesar 6,80, artinya untuk memperoleh tambahan output sebesar 1 unit diperlukan investasi sebesar 6,80. ICOR Kabupaten Minahasa Utara terus mengalami kenaikan, pada tahun 2015 Minahasa Utara memperoleh nilai ICOR sebesar 7,97, naik pada tahun 2016 menjadi 8,44 dan pada tahun 2017 mendapatkan nilai ICOR tertinggi yaitu 9,73.

Pada perhitungan nilai ICOR Kabupaten Minahasa utara untuk lag 1, didapatkan nilai ICOR pada tahun 2013 sebesar 6.21, artinya investasi yang ditanamkan pada tahun 2013 sebesar 6,21 unit akan menghasilkan output PDRB sebesar 1 unit pada tahun selanjutnya. Pada tahun 2014 nilai ICOR naik menjadi 6,75, kembali naik pada tahun 2015 sebesar 7,41 dan mendapatkan nilai ICOR tertinggi pada tahun 2016 sebesar 8,55 untuk perhitungan lag 1 . Metode perhitungan selanjutnya yang digunakan adalah perhitungan rata-rata investasi pada tahun 2013-2017, hasil perhitungan dengan menggunakan metode rata-rata investasi menunjukkan hasil ICOR sebesar 8,03, artinya diperlukan tambahan investasi sebesar 8,03 unit untuk menghasilkan output PDRB sebesar 1 unit. Dari hasil perhitungan baik lag 0, lag 1 maupun rata-rata investasi periode perhitungan 2013-2017 menunjukkan hasil ICOR yang melebihi batas efisien yakni antara 3 dan 4. Melihat kecenderungan kapasitas modal Kabupaten Minahasa Utara yang tampaknya terbatas untuk pembiayaan pembangunan, pemerintah daerah kabupaten Minahasa Utara harus merumuskan kembali sebuah kebijakan untuk target pembiayaan pembangunan yang dapat digunakan secara efisien dan tepat sasaran. Salah satu kebijakan bisa ditempuh lewat menumbuhkembangkan kategori lapangan usaha basis atau potensial di Kabupaten Minahasa Utara yang nantinya dapat menarik investor untuk dapat berinvestasi di Kabupaten Minahasa Utara. Kebijakan berikutnya adalah dengan mempermudah pengurusan izin usaha lewat kelembagaan yang saat ini sudah ada di Kabupaten Minahasa Utara dengan menyediakan informasi yang transparan kepada investor.

\section{KESIMPULAN DAN SARAN}

\section{Kesimpulan}

Berdasarkan hasil penelitian tantang Analisis Peranan Kategori Ekonomi Basis dan Efisiensi Pertambahan Investasi di Kabupaten Minahasa Utara, peneliti mengambil kesimpulan sebagai berikut:

1. Kategori ekonomi atau lapangan usaha basis di Kabupaten Minahasa utara adalah kategori pertanian, kehutanan dan perikanan dengan ratarata nilai LQ 1,34, kategori pertambanga dan penggalian dengan rata-rata LQ 2,15, kategori industri pengolahan dengan rata-rata nilai LQ 1,29 , kategori pengadaan listrik dan gas dengan rata-rata nilai LQ 1,08, kategori konstruksi dengan rata-rata nilai LQ 1,10 , kategori real estate dengan rata-rata nilai LQ 1,56, dan kategori jasa pendidikan dengan rata-rata nilai LQ 1,13 .

2. Peranan kategori ekonomi basis atau unggulan di Kabupaten Minahasa Utara dapat dilihat dari kontribusi kategori basis terhadap PDRB Kabupaten Minahasa Utara. Kategori yang memiliki kontribusi terbesar terhadap PDRB Kabupaten Minahasa Utara adalah kategori pertanian, kehutanan dan perikanan dengan kontribusi rata-rata tahun 2013-2017 sebesar 27,98\%, diikuti kategori konstruksi pada posisi kedua dengan kontribusi rata-rata sebesar $14,34 \%$, dan kategori industri pengolahan pada posisi ketiga dengan kontribusi rata-rata 13,47\% tehadap PDRB Kabupaten Minahasa Utara. Berdasarkan hasil analisis shift share, perubahan pendapatan (PDRB) di Kabupaten Minahasa Utara dibagi dalam tiga komponen sebagai berikut:

a. Peranan kategori basis lewat perhitungan regional share $(\mathrm{Nij})$ terhadap provinsi sulawesi utara juga menunjukkan hasil yang positif, artinya kategori basis di Minahasa Utara memberikan konribusi yang positif terhadap pembentukan PDRB di Provinsi Sulawesi Utara. 
b. Pada perhitungan propotional shift (Mij), beberapa kategori basis di Minahasa Utara memperoleh nilai yang negatif, kategori-kategori tersebut adalah kategori pertanian, kehutanan dan perikanan, kategori industri pengolahan, dan kategori jasa pendidikan. Kategori basil lainnya seperti kategori pertambangan dan penggalian, kategori pengadaan listrik dan gas, kategori konstruksi, dan kategori real estate memperoleh hasil yang positif terhadap perekonomian di Provinsi Sulawesi Utara.

c. Pada perhitungan differential shift (Cij) hanya kategori pengadaan listrik dan gas yang mendapatkan hasil yang negatif atau tidak memiliki daya saing terhadap kategori sejenis pada tingkat provinsi, sementara kategori basis lainnya mendapatkan hasil yang positif atau memiliki keunggulan kompetitif atau daya saing terhadap kategori sejenis pada tingkat provinsi Sulawesi Utara.

3. Hasil perhitungan Incremental Capital Output Ratio pada periode 2013-2017 di Kabupaten Minahasa Utara yang dihitung menggunakan metode standar untuk lag 0, lag 1 serta metode perhitungan rata-rata, menunjukkan hasil ICOR yang tergolong enfisien/ mendapatkan nilai ICOR diatas 4. Metode standar yang dilakukan selanjutnya adalah metode rata-rata perhitungan lag 0 tahun analisis atau lima tahun, menunjukkan nilai ICOR Kabupaten Minahasa Utara sebesar 8,01 atau menunjukkan bahwa untuk menghasilkan 1 unit ouput dibutuhkan modal atau investasi sebesar 8,01 unit.

\section{Saran}

Berdasarkan hasil penelitian yang sudah dilakukan, terdapat beberapa saran peneliti yang disampaikan sebagai berikut :

1. Pemerintah Daerah Kabupaten Minahasa Utara dalam menentukan kebijakan terkait perekonomian daerah harus memprioritaskan kategori lapangan usaha yang basis atau unggul dengan tidak mengabaikan kategori lapangan usaha lain dalam pelaksanaan perencanaan dan pembangunan daerah.
2. Perlu adanya kebijakan dalam pengelolaan output atau kontribusi yang dihasilkan oleh aktivitas kategori lapangan usaha basis di Kabupaten Minahasa Utara agar hasil yang didapatkan dari aktivitas kategori basis lebih optimal.

3. Pemerintah Kabupaten Minahasa Utara perlu meningkatkan efisiensi pertambahan investasi di Kabupaten Minahasa Utara untuk mencapai pertumbuhan ekonomi yang tinggi setiap tahun. Pengeluaran pemerintah harus diarahkan pada program atau kegiatan yang mengarah kepada peningkatan perekonomian daerah Kabupaten Minahasa Utara. Regulasi terhadap aktifitas investasi juga perlu diperhatikan demi kenyamanan calon investor yang akan berinvestasi di Minahasa Utara.

\section{DAFTAR PUSTAKA}

Arsyad, L. 2005. Ekonomi Pembangunan. Sekolah Tinggi Ilmu Ekonomi YKPN. Yogyakarta.

Badan Pusat Statistik. 2017. Minahasa Utara dalam Angka 2017. Kabupaten Minahasa Utara.

Badan Pusat Statistik. 2018. Statistik Daerah Kabupaten Minahasa Utara. Kabupaten Minahasa Utara.

Jhingan, M.L. 2010. Ekonomi Pembangunan dan Perencanaan. Jakarta: Rajawali.

Sukirno, S. 2015. Makro Ekonomi Teori Pengantar, Edisi Ketiga. PT Raja Grafindo Persada. Jakarta.

Widodo, T. 2006. Perencanaan Pembangunan: Aplikasi Komputer (Era Otonomi/ Daerah). UPP STIM YKPN, Yogayakarta. 